\title{
EVOLUTION OF PREFERENCES AND CROSS-COUNTRY DIFFERENCES IN TIME DEVOTED TO MARKET WORK
}

Luigi Bonatti 
The Discussion Paper series provides a means for circulating preliminary research results by staff of or visitors to the Department. Its purpose is to stimulate discussion prior to the publication of papers.

Requests for copies of Discussion Papers and address changes should be sent to:

\author{
Dott. Stefano Comino \\ Dipartimento di Economia \\ Università degli Studi \\ Via Inama 5 \\ 38100 TRENTO ITALIA
}




\title{
EVOLUTION OF PREFERENCES AND CROSS-COUNTRY DIFFERENCES IN TIME DEVOTED TO MARKET WORK
}

\author{
Luigi Bonatti*
}

\begin{abstract}
I model the hypothesis that preferences evolve and permanent differences in individual attitudes towards work emerge between two countries characterized initially by identical preferences as a result of a period in which only one of the two countries is subject to regulations constraining labor supply, or as a by-product of different tax rates on labor income. Hence, the elimination of these regulations may not allow the economy thus deregulated to converge to the same hours of market work per person of the other economy, and the long-run differential in market work between economies subject to different tax rates is amplified.
\end{abstract}

Keywords: Endogenous growth, time allocation, endogenous preferences, labor-market regulations, labor taxes.

JEL Classification numbers: D10, J22, O41.

* University of Trento <luigi.bonatti@unitn.it>

Postal address: Luigi Bonatti - via Luigi Canonica 29 - 20154 MILANO (Italy)

Phone: 39-02-3313522

Fax: 39-0461-882222 


\section{INTRODUCTION}

There is an increasing awareness among economists that the greater time that Americans devote to market work relative to Europeans is probably the most significant measure of the different performance of the labor market on the two sides of the Atlantic. Indeed, in 2004 the annual hours per person devoted to market work were approximately one third higher in the United States than in the two major countries of the Euro area (see Table 1). Moreover, this large differential has emerged in last thirty five years: still in the early 1970s, the level of market work per person was about the same or even lower in the US than it was in countries like France or West Germany. As a matter of fact, the hours of market work per person diverged in the $70 \mathrm{~s}$ and in the $80 \mathrm{~s}$ as a result of a pronounced downward drift in Western Europe and of an increase in the US; and this diverging trend has not been reversed in the last fifteen years, although the pace of the downward drift in hours of market work has slowed in Europe and the level of market work per person has been relatively stable in the US (see Figure 1). It is also worth to note that the large difference in market work does not imply that total work time is much higher in the US than in Western Europe since this difference appears to be partially compensated by the larger amount of time that Europeans spend working at home (see Figure 2): the available evidence shows that Europeans tend to self-produce part of those services that Americans buy on the market (Davis and Henrekson, 2004; Olovsson, 2004; Freeman and Schettkat, 2005; Rogerson, 2005; Burda et al., 2006). In this regard, it is significant the reduction in time devoted to home production that has occurred in the United States: time use surveys document that the small increase in hours of market work that has characterized the United States over the last three decades has been paralleled by an increase in leisure time. ${ }^{1}$

Recent attempts to explain the diverging trend in labor supply have focused on the bigger role played in Europe by labor market regulation and unionization (see Alesina et al., 2005), and on the higher tax rate on labor income in Europe relative to the US (see Prescott, 2004). However, both these explanations are not fully satisfactory. Scope of this paper is to supplement them by showing that they can better fit the stylized facts if one hypothesizes that individual preferences concerning the trade off between the time devoted to

\footnotetext{
${ }^{1}$ By using time use surveys, Aguiar and Hurst (2006) document that hours per week spent in non-market work fell by $11 \%$ in the US over the period $1975-2003$, thus counterbalancing the $2.7 \%$ increase in hours of market work over the same period and leading to a reduction in hours per week of total (market and non-market) work.
} 
leisure and consumption are not constant but evolve in response to the society's experiences in matter of working time. In other words, I assume that the evolution of preferences regarding the use of time is the result of a social process whereby the emergence and diffusion of certain behavior tends to reinforce individual attitudes and habits that are conducive to that behavior.

The paper is organized as follows: section 2 discusses the literature that motivates the paper, section 3 presents the basic model; section 4 characterizes the equilibrium trajectories of two economies when in one of them labor supply is temporarily subject to institutional constraints; section 5 studies the two economies when in one of them labor is taxed more heavily; section 6 concludes.

TABLE 1. Countries differences in levels and trends of market work per 15-64 year olds (annual hours worked per person of working age ${ }^{\text {a) }}$

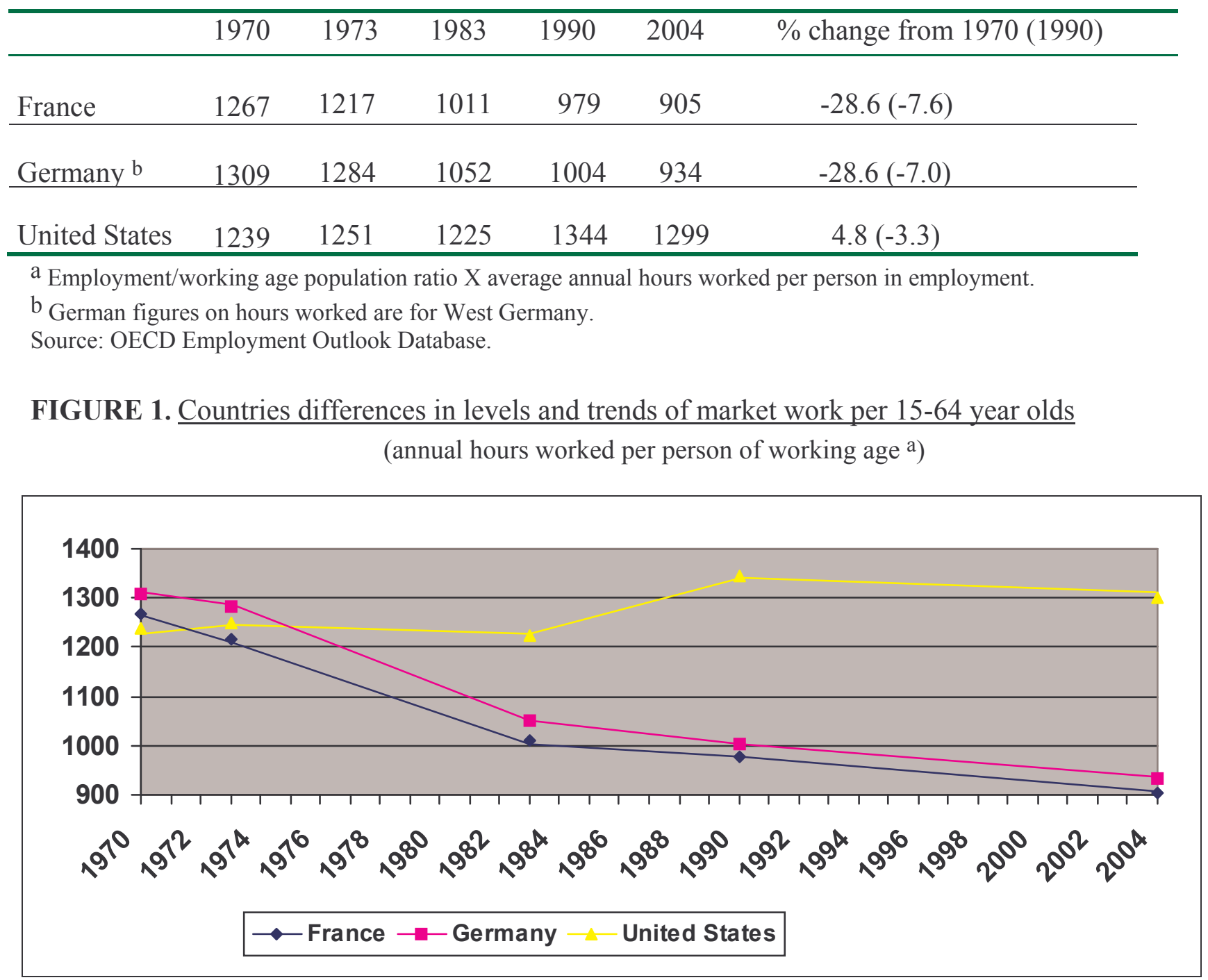

a Employment/working age population ratio $\mathrm{X}$ average annual hours worked per person in employment. German figures on hours worked are for West Germany. Source: OECD Employment Outlook Database. 
FIGURE 2. Differences in time use between Germany and United States (early 2000s a) (average minutes per day for person aged 20-74)

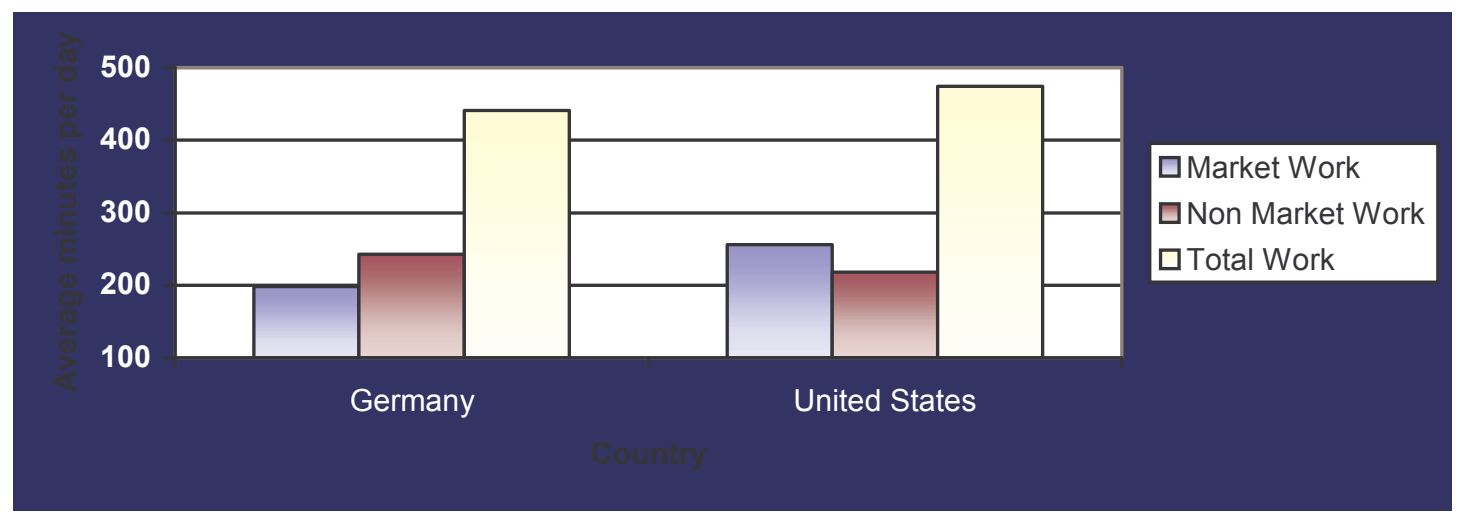

a For Germany: 2001-02; for United States: 2003.

Source: Burda et al. (2006).

\section{MOTIVATIONS}

According to Alesina et al. (2005), labor market regulation and unionization which imposed lower working hours with equal or increasing pay in Continental Europe are the dominant factors in explaining why market hours worked per adult are nowadays much less in Europe than in the US, although in the early 1970s were about the same on the two sides of the Atlantic. Alesina et al. (2005) also emphasize that the importance of labor market regulation and unionization in Europe has changed over time: it sharply increased in the late 1960s, reaching its peak in most European countries in late 1970s/early 1980s, namely precisely in those years in which a difference in working hours between the US and Europe emerged. However, this differential has kept growing also in the following decades when unions density went down (see Table 2) and labor regulations were softened in most European countries. ${ }^{2}$ This is puzzling since one may expect that--if the factors stressed by Alesina et al. (2005) were so important to explain the emergence of a growing difference in hours of market work between US and Europe - their (partial) removal should have stopped and even reversed this diverging trend. The model presented here shows that this is actually the case when one does not account for the tendency of the preferences concerning the trade off between leisure and consumption to evolve in response to the people's experiences in matter of time allocation: if

\footnotetext{
${ }^{2}$ Assessing the impact of labor market institutions on the performance of the European labor market in the last 35 years, Blanchard and Wolfers (2000, p.16) reach the following conclusion: "There was an increase in employment-unfriendly institutions in the late 1960s and early 1970s. Since then, there appears to have been a small but steady decline."
} 
preferences are time invariant, the model predicts that a regime shift removing the restrictions that have constrained labor supply for a prolonged period of time allows the economy thus deregulated to converge to the same worked hours of the economy that never was subject to such restrictions. In contrast, by accounting for the evolution of preferences, the model predicts that the removal of the restrictions that have constrained labor supply for a prolonged period of time may not be sufficient to allow the economy thus deregulated to converge to the same worked hours of the economy that never was subject to such restrictions. This captures the idea that policies or events affecting market work time for a limited period of time may have permanent effects on labor supply and economic growth, since the subjective value that individuals attribute to leisure relative to consumption reflects collective habits and social attitudes which are shaped by society's past experiences in matter of time allocation. The fact that labor supply is influenced by the subjective value that individuals attribute to leisure relative to consumption, together with the fact that individual preferences attaching a relatively high (low) weight to non-working time tend to emerge in societies that have experienced in the past low (high) levels of worked hours, creates the potential for the existence of multiple balanced growth paths and for path dependency. Hence, structurally similar economies in which the allocation of time was subject for a certain period to different institutional constraints may converge to different balanced growth paths, thus making permanent those differentials in market time and growth rate that emerged when their institutions diverged. In other words, sufficiently prolonged differences in institutions and policies may determine differences in behavioral habits that have permanent effects on economic outcomes.

According to Prescott (2004), differences in the marginal tax rate on labor income can explain almost entirely the difference in hours of market work between French, Germans and Italians on one side and Americans on the other side. However, as critics point out (see Alesina et al., 2005), the increase in tax rates was concentrated in Continental Europe almost exclusively in the 1970s and in the 1980s (see Table 3), while the decline in worked time continued also during the 1990s (see Table 1 and Figure 1). Furthermore, an explanation of the large differential in market work between US and Europe entirely based on labor taxes cannot be reconciled with the small tax effects on labor inputs found by cross-country studies (see Nickell, 2003). This general conclusion is reinforced by microeconometric studies which show that the role of the difference in tax rates in generating such a differential cannot be inferred from the individual labor supply 
elasticities alone (see Davis and Henrekson, 2004; Alesina et al., 2005). Indeed, one should also consider that countries with higher tax rates tend to have more generous tax-funded public programs and government transfers that weaken labor supply incentives. ${ }^{3}$ Even accounting for these indirect effects of heavier taxation, the difference in tax rates can hardly explain the entire differential in market time between the EU and the US without some other mechanism that amplifies its effects.

In the search of a mechanism amplifying the effects of some policy or institutional difference on the cross-country differential in market work, Alesina et al. (2005) invoke the possible existence of a social multiplier, namely that there may be positive complementarities across people in the enjoyment of leisure time. ${ }^{4}$ Although these positive spillovers may help explaining why a cross-country difference in tax rates can cause a large gap in market work even when the individual labor supply elasticities are low, they do not contribute to explain why a diverging trend in worked hours continued even once that a difference in tax rates had stopped growing. An explanation of the large differential in market work between United States and Europe which relies mainly on the possibility that in every period multiple equilibria exist because of the presence of interdependent preferences and/or externalities generated by individual choices can hardly account for the persistency of this differential: why year after year Europeans coordinate on a low-market work equilibrium while Americans coordinate on a high-market work equilibrium? In other words, this simple multiple equilibria story can fit the stylized facts only if one assumes the occurrence of a very unlikely event, that is the repeated emergence--period after period and for a prolonged lapse of time--of a low-market work equilibrium in Europe and of a high-market work equilibrium in the US. In contrast, the model presented here can explain this persistency by introducing the process whereby individual preferences

\footnotetext{
${ }^{3}$ However, the structure of public expenditures matters: market work tends to increase when a larger share of public expenditures is devoted to the provision of goods that are close substitutes for home produced goods like day care or elder care. According to Ragan (2005), this may explain why the tax wedge alone may misstate the marginal incentives to work faced by Scandinavians and why the level of labor supply is very low in European countries where the tax wedges are smaller than in Scandinavia.

${ }^{4}$ According to Glaeser et al. (2002), a social multiplier is at work whenever aggregate relationships overstate individual elasticities because of the presence of positive social interactions, or strategic complementarities.
} 
in matter of time allocation may evolve in time in response to changes in social norms and habits, which in their turn reflect past experiences in people's use of time.

Also Blanchard (2004) maintains that the evolution of tax rates may explain only a minor portion of the diverging trend in market work between the EU and the US, with a large role left for preferences. However, Blanchard claims that people in the EU and the US have different preferences, whereas I argue that preferences were initially similar, but have become different as a result of different institutions and policies. Indeed, by recognizing that the preferences concerning the allocation of time evolve in response to past experiences in matter of working time, I introduce a sort of dynamic multiplier that amplifies and propagates the effects of changes in taxes, thus explaining both the amplitude of the differential in market time and the continuation of the diverging trend in worked hours that followed a permanent increase in the cross-country difference in tax rates.

Evidence on individual preferences concerning time use can be obtained from attitude surveys. These surveys permit to track the evolution of workers' attitudes within a country and to compare attitudes across countries (see OECD, 1998). Surveys commissioned by the European Commission show that the direction of change between 1985 and 1994 in the European countries is towards an increase in the fraction of workers expressing a preference for a reduction in working hours rather than for more earnings. ${ }^{5}$ It is worth to note that this increase in the fraction of workers displaying a desire for fewer work hours has occurred in a period in which European workers have reduced their work hours. Moreover, data from these surveys and from surveys carried out under the auspices of the International Social Science Programme $(\text { ISSP })^{6}$ show that countries in which average hours of market work per person are relatively low tend to

\footnotetext{
${ }^{5}$ The European Commission question was: "If the choice were offered in next pay round between an increase in pay for the same hours of work and shorter working time for the same pay you get now, which would you prefer?". In 1985, on average, $62 \%$ of EU workers would prefer "more earnings" as opposed to $31 \%$ opting for "fewer hours", while in 1994, on average, $56 \%$ of EU workers expressed a preference for increased earnings as opposed to $38 \%$ expressing a desire for hours reduction.

${ }^{6}$ The ISSP question was: "Think of the number of hours you work and the money you earn in your main job, including regular overtime. If you had one of these three choices, which of the following would you prefer? i) Work longer hours
} 
display a stronger desire for fewer hours than for more earnings. As a substantial confirm that actual and desired work hours tend to move in the same direction, Bell and Freeman (2001) report data on German workers for the period 1985-1995 showing that--in spite of the drop in hours worked over the decade--the desired work hours tend to decline (see Table 4). ${ }^{7}$ A legitimate interpretation of this evidence consistent with the hypothesis underlying the model presented here is that work preferences are influenced by actual experiences concerning work hours and that in their turn contribute to determine future working time. Even more interestingly from the viewpoint inspiring this paper, Bell and Freeman (1995) find that the USGerman difference in work preferences changed dramatically over time: in the 1960s German workers both worked longer hours and expressed a stronger preference for longer hours than their American counterparts, while in the 1989 the position of the two countries reversed, with the US employees both working longer hours and indicating a greater desire for longer hours (see Table 5). On the basis of this evidence, Bell and Freeman conclude that the gap in work preferences between Germans and Americans, like the gap in actual hours, must have developed in the 1970s and 1980s. ${ }^{8}$

The idea that individual preferences in matter of time allocation reflect social norms and collective habits which may be regarded as "social (collective) capital" that accumulates or decumulates over time, and that major institutional or macroeconomic shocks may drastically influence their evolution was discussed by Lindbeck (1995) and Lindbeck et al. (1999). An important implication of this idea is that the equilibrium position of the economy is path dependent, since individual attitudes and propensities at a specific point in time depend on previous behavior by society's members that may reinforce or undermine the existing social

and earn more money; ii) Work the same number of hours and earn the same money; iii) Work fewer hours and earn less money".

${ }^{7}$ In the $1985-1995$ pool sample, $46 \%$ of German workers are roughly satisfied with their hour worked; $47 \%$ would prefer fewer hours, and 7\% would desire more work.

${ }^{8}$ Bell and Freeman (1995 and 2001) argue that the difference in wage inequality between the US and Germany is a major factor underlying the difference in hours worked and in work preferences between the two countries. 
norms and collective habits. ${ }^{9}$ In sum, this literature argues that individual preferences and attitudes are strongly influenced by social norms and collective habits, which in their turn are reinforced (weakened) whenever the relevant population conforms to them more (less) intensely. Institutions and policies may interfere in this process by changing the incentives of adhering to norms and conforming to habits and routines. In particular, I follow the literature that emphasizes the role of social norms and habits formation in shaping individual behavior in the labor market (Blomquist, 1993; Woittiez and Kapteyn, 1998; Faria and León-Ledesma, 2004; Gurdgiev, 2004; Jakee and Guang-Zhen, 2005; Aronsson and Sjögren, 2006). Hence, I assume that individual preferences about time allocation reflect work hour norms and collective habits concerning the use of time which prevail in a given society at a certain point in time. This can explain why people living in a society where certain social norms and habits regarding the use of time are dominant are inclined to develop different attitudes with respect to this use than their counterparts living in a society characterized by other social norms and collective habits. In their turn, these social norms and habits are periodically updated as a result of the prevailing experience in matter of work hours and time use. Issues like the "normal" number of work hours per week or of paid holidays per year, or the "acceptable" amount of time to spend within the family or meeting friends, are very sensitive to people's perceptions of what others living in the same community and society are doing with their time. Therefore, whenever a large number of individuals change their use of time because of institutional constraints or policies affecting the opportunity cost of time, also social norms and habits in matter of time allocation tend to be revised and to evolve in response to these new collective experiences.

TABLE 2. Union density in France and (West) Germany

(percent of employed workers who are union members)

$$
\text { 1965-72 1973-79 1980-87 1988-95 1996-98 }
$$

\begin{tabular}{|l|l|l|l|l|l|}
\hline France & 21 & 21 & 16 & 10 & 10 \\
\hline (West) Germany & 32 & 35 & 34 & 31 & 27 \\
\hline
\end{tabular}

Source: Ebbinghaus and Visser, 2000.

\footnotetext{
${ }^{9}$ Among the significant contributions concerning the formation, transmission and evolution of norms and cultural values, see Arrow (1974), North (1990), Becker and Madrigal (1994), Greif (1994), Becker (1996), Kreps (1997), Posner (1997), Bisin and Verdier (1998), Bowles (1998), Fernandez e Fogli (2005).
} 
TABLE 3. Total tax on labor a

(total tax rate in percentage)

$1965-72 \quad 1973-79 \quad 1980-87 \quad 1988-95 \quad 1996-2000$

\begin{tabular}{|c|c|c|c|c|c|}
\hline France & 57 & 60 & 65 & 67 & 68 \\
\hline (West) Germany & 44 & 48 & 50 & 52 & 50 \\
\hline United States & 37 & 42 & 44 & 45 & 45 \\
\hline
\end{tabular}

a Payroll tax rate plus income tax rate plus consumption tax rate.

Source: Nickell, 2003.

TABLE 4. German actual and desired work hours

(GSOEPb data from various years)

$\begin{array}{lllllll}1985 & 1990 & 1991 & 1992 & 1993 & 1994 & 1995\end{array}$

\begin{tabular}{|l|l|l|l|l|l|l|l|}
\hline Usual weekly hours & 40.3 & 39.5 & 39.3 & 39.1 & 38.8 & 38.6 & 38.5 \\
\hline Desired weekly hours & 35.3 & 35.1 & 34.5 & 34.7 & 34.6 & 34.8 & 34.0 \\
\hline
\end{tabular}

a Data are for West German workers with at least 5 hours of work per week.

b German Socio-Economic Panel. The GSOEP question was: "If you could chose the extent of your hours at work, taking into account that earnings would change corresponding to the time, how many hours would you work?"

Source: Bell and Freeman, 2001.

TABLE 5. German and US preferences for more or less work

\begin{tabular}{|c|c|c|c|c|}
\hline & $\begin{array}{c}\text { Germans } \\
(1960 \mathrm{~s})\end{array}$ & $\begin{array}{c}\text { Americans } \\
(1960 \mathrm{~s})\end{array}$ & $\begin{array}{c}\text { Germans } \\
(1989)\end{array}$ & $\begin{array}{c}\text { Americans } \\
\text { (1989) }\end{array}$ \\
\hline More hours/more pay & $44 \%$ & $34 \%$ & $14 \%$ & $33 \%$ \\
\hline Same hours/same pay & $49 \%$ & $56 \%$ & $76 \%$ & $62 \%$ \\
\hline Less hours/less pay & $7 \%$ & $10 \%$ & $10 \%$ & $5 \%$ \\
\hline
\end{tabular}

a Data for the 1960s are from responses to the following question: "Some people would like to work more hours a week if they could be paid for it. Others would prefer to work fewer hours per week even if they earned less. How do you feel about this?" (see Katona et al., 1971). Data for 1989 are from ISSP.

Source: Bell and Freeman, 1995.

\section{THE BASIC MODEL}

I consider an economy in discrete time with an infinite time horizon. In this economy there are firms and households. 


\subsection{The firms}

For simplicity and without loss of generality, it is assumed that there is a fixed and large number (normalized to be one) of perfectly competitive firms that are identical and produce the single good $\mathrm{Y}_{\mathrm{t}}$ according to the technology

$$
\mathrm{Y}_{\mathrm{t}}=\mathrm{A}_{\mathrm{t}} \mathrm{K}_{\mathrm{t}}^{\theta} \mathrm{h}_{2 \mathrm{t}}^{1-\theta}, 0<\theta<1
$$

where $A_{t}$ denotes the state of technology in period $t, K_{t}$ is the amount of capital rent by the firm in $t$ and $h_{2 t}$ are the units of labor employed by the firm in $t$. It is assumed that $A_{t}$ is a positive function of the stock of capital existing in the economy: $\mathrm{A}_{\mathrm{t}}=\mathrm{K}_{\mathrm{t}}^{1-\theta}$ (consistently with this formal set-up, one can interpret technological progress as labor augmenting). This assumption combines the idea that learning-by-doing works through each firm's (physical) capital utilization and the idea that knowledge and productivity gains spill over instantly across all firms (see Barro and Sala-i-Martin, 1995). Therefore, in accordance with Frankel (1962), it is supposed that although $A_{t}$ is endogenous to the economy, each firm takes it as given, since a single agent's investment decisions have only a negligible effect on the aggregate stock of capital.

In each $\mathrm{t}$, the representative firm chooses $\mathrm{h}_{2 \mathrm{t}}$ and $\mathrm{K}_{\mathrm{t}}$ in order to maximize its profits, which are given by

$$
\pi_{\mathrm{t}}=\mathrm{Y}_{\mathrm{t}}-\mathrm{W}_{\mathrm{t}} \mathrm{h}_{2 \mathrm{t}}-\mathrm{R}_{\mathrm{t}} \mathrm{K}_{\mathrm{t}}
$$

where $R_{t}$ is the capital rental rate and $W_{t}$ is the wage rate. Note that $Y_{t}$ is the numeraire of the system and its price is set to be one.

\subsection{The households}

For simplicity and without loss of generality, it is assumed that the population is constant and that each household contains one adult, working member of the current generation. Thus, there is a fixed and large number (normalized to be one) of identical adults who take account of the welfare and resources of their actual and prospective descendants. Following Barro and Sala-i-Martin (1995) I model this intergenerational interaction by imagining that the current generation maximizes utility and incorporates a budget constraint over an infinite future. That is, although individuals have finite lives, I consider immortal extended families 
(“dynasties"). ${ }^{10}$ Finally, I assume that agents' expectations are rational, in the sense that they are consistent with the real processes followed by the relevant variables. In this framework, in which there is no source of random disturbances, this implies perfect foresight.

In each $t$, the utility of the representative household is an increasing function of two consumption commodities. The representative household produces the first commodity, $\mathrm{C}_{\mathrm{t}}$, by combining a market good, $\mathrm{x}_{\mathrm{t}}$, with the time that it devotes to home production, $\mathrm{h}_{1 \mathrm{t}}$, according to a CES production function with elasticity parameter $\sigma$ (see Aguiar and Hurst, 2006):

$$
\mathrm{C}_{\mathrm{t}}=\left(\mathrm{x}_{\mathrm{t}}^{\frac{\sigma-1}{\sigma}}+\mathrm{h}_{1 \mathrm{t}}^{\frac{\sigma-1}{\sigma}}\right)^{\frac{\sigma}{\sigma-1}}, \sigma>1 .
$$

Notice that $\sigma>1$ implies that $x_{t}$ and $h_{1 t}$ are substitutes in production of $C_{t}$. Furthermore, the representative household produces the second commodity by using only time as an input. Therefore, this second commodity can be interpreted as leisure, $\mathrm{L}_{\mathrm{t}}$, "in the sense that market goods cannot be used as a substitute for time in production" (Aguiar and Hurst, 2006, p. 7).

Households' utility is assumed to be separable in $\mathrm{C}_{\mathrm{t}}$ and $\mathrm{L}_{\mathrm{t}}$ :

$$
\mathrm{U}_{\mathrm{t}}=\ln \left(\mathrm{C}_{\mathrm{t}}\right)+\alpha_{\mathrm{t}} \ln \left(\mathrm{L}_{\mathrm{t}}\right), \alpha_{\mathrm{t}}>0 \text {, }
$$

where $\alpha_{t}$ measures the subjective value that the representative household attributes to leisure relative to consumption in $\mathrm{t}$.

The time that the representative household devotes to market work, $\mathrm{h}_{2 \mathrm{t}}$, is subtracted to home production and to leisure. Indeed, the household is subject to the time constraint

$$
\mathrm{h}_{1 \mathrm{t}}-\mathrm{h}_{2 \mathrm{t}}-\mathrm{L}_{\mathrm{t}} \leq \mathrm{N}
$$

where $\mathrm{N}$ is the representative household's total time. ${ }^{11}$

\footnotetext{
${ }^{10}$ As Barro and Sala-i-Martin (1995, p. 60) point out, "this setting is appropriate if altruistic parents provide transfers to their children, who give in turn to their children, and so on. The immortal family corresponds to finite-lived individuals who are connected via a pattern of operative intergenerational transfers that are based on altruism".

${ }^{11}$ As in Prescott (2004) and Alesina et al. (2005), we simplify by treating hours of work as continuous measures and ignoring the binary choice whether to participate or not in the labor market.
} 
The period budget constraint of the representative household is the following:

$$
\mathrm{K}_{\mathrm{t}+1}+\mathrm{x}_{\mathrm{t}} \leq \mathrm{K}_{\mathrm{t}}(1-\delta)+\pi_{\mathrm{t}}+\mathrm{R}_{\mathrm{t}} \mathrm{K}_{\mathrm{t}}+\mathrm{W}_{\mathrm{t}} \mathrm{h}_{2 \mathrm{t}}, 0<\delta<1, \mathrm{~K}_{0} \text { given, }
$$

where $\delta$ is a parameter measuring capital depreciation.

The problem of the representative household amounts to choose $\left\{\mathrm{K}_{\mathrm{t}+1}\right\}_{0}^{\infty},\left\{\mathrm{x}_{\mathrm{t}}\right\}_{0}^{\infty}$, $\left\{\mathrm{h}_{1 \mathrm{t}}\right\}_{0}^{\infty}$ and $\left\{\mathrm{h}_{2 \mathrm{t}}\right\}_{0}^{\infty}$ in order to maximize

$$
\sum_{t=0}^{\infty} \beta{ }^{t} U_{t}, 0<\beta<1,
$$

subject to (5) and (6), where $\beta$ is a time-preference parameter.

\subsection{Preferences' evolution}

Individual preferences concerning the trade-off between consumption and leisure are assumed to be externally influenced, in the sense that they are affected by social norms and habits whose current state depends on the average leisure enjoyed by the households in the past. Indeed, the average number of hours devoted to leisure can be interpreted as a proxy of the population's attitudes toward leisure. Consistently, the dependence of individual preferences on social habits is modeled by making $\alpha_{t}$-the parameter measuring the subjective value attributed by the representative household to leisure relative to consumption-an increasing function of $\mathrm{H}_{t}$, namely of the stock of social habits whose current level depends positively on the average leisure enjoyed by the households in the past: ${ }^{12}$

$$
\alpha_{\mathrm{t}}=m\left(\mathrm{H}_{\mathrm{t}}\right), m^{\prime}>0,
$$

where the stock $\mathrm{H}_{\mathrm{t}}$ evolves according to (see, e.g., Faria and León-Ledesma, 2004; Gurdgiev, 2004):

$$
\mathrm{H}_{\mathrm{t}+1}=\mathrm{H}_{\mathrm{t}}+\lambda\left(\mathrm{L}_{\mathrm{t}}-\mathrm{H}_{\mathrm{t}}\right), 0<\lambda<1, \mathrm{H}_{0} \text { given. }{ }^{13}
$$

Since $\mathrm{H}_{\mathrm{t}}$ depends on the average leisure time in the preceding periods, its motion is the result of a social process, and the actions of a single household have only a negligible effect on the evolution of preferences. Thus, it can neglect the impact of its choices on this evolution.

\footnotetext{
${ }^{12}$ Also in Blomquist (1993), some utility function parameters are functions of the average values of consumption and hours of work. However, Blomquist's static model cannot capture the process whereby preferences evolve in time.

${ }^{13}$ Since households are assumed to be identical, average leisure in period $t$ is equal to the leisure enjoyed by the representative household in $\mathrm{t}$
} 


\subsection{Market-clearing conditions}

Equilibrium in the market for the product implies

$$
\mathrm{K}_{\mathrm{t}+1}+\mathrm{x}_{\mathrm{t}}=\mathrm{K}_{\mathrm{t}}(1-\delta)+\mathrm{Y}_{\mathrm{t}}
$$

Equilibrium in the markets for labor and for capital implies, respectively

$$
\mathrm{h}_{2 \mathrm{t}}^{\mathrm{d}}=\mathrm{h}_{2 \mathrm{t}}^{\mathrm{s}}
$$

and

$$
\mathrm{K}_{\mathrm{t}}^{\mathrm{d}}=\mathrm{K}_{\mathrm{t}}^{\mathrm{s}} \text {. }
$$

\section{REMOVAL OF THE RESTRICTIONS CONSTRAINING LABOR SUPPLY AND CONVERGENCE IN WORKED HOURS PER PERSON}

In this section it is assumed that two countries, US and EU, share the same parameter values and the same initial condition $\mathrm{H}_{0}$. However, the two countries are assumed to differ because the US labor supply is never constrained by labor market regulations and/or union ceilings, while the EU labor supply is subject to such imposition for some initial time interval $\left(\mathrm{h}_{2 \text { eut }} \leq \overline{\mathrm{h}}_{2}\right.$ for $\left.\mathrm{t} \in\left[0, \mathrm{t}^{\#}\right), \mathrm{t}^{\#}>0\right)$. In period $\mathrm{t}^{\#}$ this restriction is removed in the $\mathrm{EU}$, and from period $\mathrm{t}^{\#}$ on labor supply is freely determined by the market in both countries. It is also assumed that the change in the EU labor market regime occurring in $t^{\#}$ is unanticipated: EU economic agents made their decisions in any $\mathrm{t} \in\left[0, \mathrm{t}^{\#}\right)$ on the expectation that $\mathrm{h}_{2 \text { eut }} \leq \overline{\mathrm{h}}_{2} \forall \mathrm{t}$. The analysis is conducted both under the hypothesis that — consistently with the model presented in the previous sectionpreferences concerning the trade off between leisure and consumption evolve in time and under the alternative hypothesis that they do not change.

\subsection{Evolving preferences}

Suppose that social habits affecting preferences evolve in time according to (9) and that labor supply is not constrained by labor market regulations and/or union ceilings. In this case, the equilibrium path of the economy is governed by the following system of difference equations in $h_{2 t}, H_{t}$ and $v_{t} \equiv \frac{h_{1 t}}{x_{t}}$ (see the Appendix for the derivation): 
$\Psi\left(\mathrm{h}_{2 \mathrm{t}+1}, \mathrm{H}_{\mathrm{t}+1}, \mathrm{v}_{\mathrm{t}+1}, \mathrm{~h}_{2 \mathrm{t}}, \mathrm{H}_{\mathrm{t}}, \mathrm{v}_{\mathrm{t}}\right)=\frac{h_{1}\left(\mathrm{~h}_{2 \mathrm{t}+1}, \mathrm{H}_{\mathrm{t}+1}, \mathrm{v}_{\mathrm{t}+1}\right)}{\mathrm{v}_{\mathrm{t}+1}}\left(1+\mathrm{v}_{\mathrm{t}+1}^{\frac{\sigma-1}{\sigma}}\right)-\frac{h_{1}\left(\mathrm{~h}_{2 \mathrm{t}}, \mathrm{H}_{\mathrm{t}}, \mathrm{v}_{\mathrm{t}}\right)}{\mathrm{v}_{\mathrm{t}}}\left(1+\mathrm{v}_{\mathrm{t}}^{\frac{\sigma-1}{\sigma}}\right) \beta\left[1-\delta+\theta \mathrm{h}_{2 \mathrm{t}+1}^{1-\theta}\right]=0$

$$
\Omega\left(\mathrm{H}_{\mathrm{t}+1}, \mathrm{~h}_{2 \mathrm{t}}, \mathrm{H}_{\mathrm{t}}, \mathrm{v}_{\mathrm{t}}\right)=\mathrm{H}_{\mathrm{t}+1}-\mathrm{H}_{\mathrm{t}}-\lambda\left[L\left(\mathrm{~h}_{2 \mathrm{t}}, \mathrm{H}_{\mathrm{t}}, \mathrm{v}_{\mathrm{t}}\right)-\mathrm{H}_{\mathrm{t}}\right]
$$

$\Phi\left(\mathrm{h}_{2 \mathrm{t}+1}, \mathrm{H}_{\mathrm{t}+1}, \mathrm{v}_{\mathrm{t}+1}, \mathrm{~h}_{2 \mathrm{t}}, \mathrm{H}_{\mathrm{t}}, \mathrm{v}_{\mathrm{t}}\right)=\frac{\mathrm{h}_{2 \mathrm{t}}^{\theta} m\left(\mathrm{H}_{\mathrm{t}}\right)\left(1-\delta+\mathrm{h}_{2 \mathrm{t}}^{1-\theta}\right)}{(1-\theta) L\left(\mathrm{~h}_{2 \mathrm{t}}, \mathrm{H}_{\mathrm{t}}, \mathrm{v}_{\mathrm{t}}\right)}-\left(1+\mathrm{v}_{\mathrm{t}}^{\frac{\sigma-1}{\sigma}}\right)^{-1}-\frac{\mathrm{h}_{2 \mathrm{t}+1}^{\theta} m\left(\mathrm{H}_{\mathrm{t}+1}\right) \beta\left(1-\delta+\theta \mathrm{h}_{2 \mathrm{t}+1}^{1-\theta}\right)}{(1-\theta) L\left(\mathrm{~h}_{2 \mathrm{t}+1}, \mathrm{H}_{\mathrm{t}+1}, \mathrm{v}_{\mathrm{t}+1}\right)}=0$

where $\mathrm{h}_{1 \mathrm{t}}=h_{1}\left(\mathrm{~h}_{2 \mathrm{t}}, \mathrm{H}_{\mathrm{t}}, \mathrm{v}_{\mathrm{t}}\right)=\left(\mathrm{N}-\mathrm{h}_{2 \mathrm{t}}\right) \mathrm{v}_{\mathrm{t}}^{\frac{\sigma-1}{\sigma}}\left[m\left(\mathrm{H}_{\mathrm{t}}\right)\left(1+\mathrm{v}_{\mathrm{t}}^{\frac{\sigma-1}{\sigma}}\right)+\mathrm{v}_{\mathrm{t}}^{\frac{\sigma-1}{\sigma}}\right]^{-1}$ and

$\mathrm{L}_{\mathrm{t}}=L\left(\mathrm{~h}_{2 \mathrm{t}}, \mathrm{H}_{\mathrm{t}}, \mathrm{v}_{\mathrm{t}}\right)=\mathrm{N}-h_{1}\left(\mathrm{~h}_{2 \mathrm{t}}, \mathrm{H}_{\mathrm{t}}, \mathrm{v}_{\mathrm{t}}\right)-\mathrm{h}_{2 \mathrm{t}}$. Notice that $\frac{\partial \mathrm{h}_{1 \mathrm{t}}}{\partial \mathrm{h}_{2 \mathrm{t}}} \leq 0, \frac{\partial \mathrm{h}_{1 \mathrm{t}}}{\partial \mathrm{H}_{\mathrm{t}}} \leq 0, \frac{\partial \mathrm{h}_{1 \mathrm{t}}}{\partial \mathrm{v}_{\mathrm{t}}}>0, \frac{\partial \mathrm{L}_{\mathrm{t}}}{\partial \mathrm{h}_{2 \mathrm{t}}}<0$, $\frac{\partial \mathrm{L}_{\mathrm{t}}}{\partial \mathrm{H}_{\mathrm{t}}} \geq 0$ and $\frac{\partial \mathrm{L}_{\mathrm{t}}}{\partial \mathrm{v}_{\mathrm{t}}}<0$ : both domestic work and leisure tend to decrease as market work increases, while they tend to have opposite reactions as the stock $\mathrm{H}_{\mathrm{t}}$ and the ratio $\mathrm{v}_{\mathrm{t}}$ become higher.

Together with (13)-(15), an equilibrium path must satisfy the transversality condition (see the Appendix)

$$
\lim _{\mathrm{t} \rightarrow \infty} \beta^{\mathrm{t}} \frac{m\left(\mathrm{H}_{\mathrm{t}}\right) \mathrm{h}_{2 \mathrm{t}}^{\theta}}{(1-\theta) L\left(\mathrm{~h}_{2 \mathrm{t}}, \mathrm{H}_{\mathrm{t}}, \mathrm{v}_{\mathrm{t}}\right)}=0
$$

A balanced growth path (BGP) can be characterized by setting $\mathrm{h}_{2 \mathrm{t}+1}=\mathrm{h}_{2 \mathrm{t}}=\mathrm{h}_{2}, \mathrm{H}_{\mathrm{t}+1}=\mathrm{H}_{\mathrm{t}}=\mathrm{H}$ and $\mathrm{v}_{\mathrm{t}+1}=\mathrm{v}_{\mathrm{t}}=\mathrm{v}$ in (13)-(15). Along a BGP, $\mathrm{Y}_{\mathrm{t}}$ grows at a rate $\mu=\beta\left(1-\delta+\theta \mathrm{h}_{2}^{1-\theta}\right)-1, \mu_{\mathrm{t}} \equiv \frac{\mathrm{Y}_{\mathrm{t}+1}-\mathrm{Y}_{\mathrm{t}}}{\mathrm{Y}_{\mathrm{t}}}$, and $\mathrm{L}=\mathrm{H}$. Moreover, one can check that it is possible to have more than one triple $\left(h_{2}, H, v\right)$ such that: i) it satisfies the system consisting of $\Psi()=0,. \Omega()=$.0 and $\Phi()=$.0 with $\mathrm{h}_{2 \mathrm{t}+1}=\mathrm{h}_{2 \mathrm{t}}=\mathrm{h}_{2}, \mathrm{H}_{\mathrm{t}+1}=\mathrm{H}_{\mathrm{t}}=\mathrm{H}$ and $\mathrm{v}_{\mathrm{t}+1}=\mathrm{v}_{\mathrm{t}}=\mathrm{v}$; ii) it is consistent with $\mu>0$ (perpetual growth), and iii) it is locally stable. Supposing that there exist two of these BGP triples, say $\left(\mathrm{h}_{2 \mathrm{eu}}^{*}, \mathrm{H}_{\mathrm{eu}}^{*}, \mathrm{v}_{\mathrm{eu}}^{*}\right)$ and $\left(\mathrm{h}_{2 \mathrm{us}}^{*}, \mathrm{H}_{\mathrm{us}}^{*}, \mathrm{v}_{\mathrm{us}}^{*}\right)$, they are such that $\mathrm{h}_{2 \mathrm{eu}}^{*}<\mathrm{h}_{2 \mathrm{us}}^{*}, \mathrm{H}_{\mathrm{eu}}^{*}>\mathrm{H}_{\mathrm{us}}^{*}$ and $\mathrm{v}_{\mathrm{eu}}^{*}=\mathrm{v}_{\mathrm{us}}^{*}=0$, thus implying that $0<\mu_{\mathrm{eu}}^{*}<\mu_{\mathrm{us}}^{*}$, namely that the rate of output growth is higher along the 
BGP characterized by $\left(\mathrm{h}_{2 \mathrm{us}}^{*}, \mathrm{H}_{\mathrm{us}}^{*}, \mathrm{v}_{\mathrm{us}}^{*}\right)$ than along the BGP characterized by $\left(\mathrm{h}_{2 \mathrm{eu}}^{*}, \mathrm{H}_{\mathrm{eu}}^{*}, \mathrm{v}_{\mathrm{eu}}^{*}\right)$ (see the Appendix).

The existence of multiple stable BGP triples $\left(\mathrm{h}_{2}, \mathrm{H}, \mathrm{v}\right)$ is possible because when households attribute a low (high) weight to leisure in their utility function, hours devoted to leisure per person tend to be low (high), thus reinforcing those social habits and norms that determine a relatively low (high) subjective value of leisure relative to consumption. In this way, policies or events that affect worked hours for a limited period of time may have permanent effects on individual preferences, labor supply and economic growth.

The system obtained by linearizing (13)-(15) in a neighborhood of $\left(\mathrm{h}_{2 \mathrm{i}}^{*}, \mathrm{H}_{\mathrm{i}}^{*}, \mathrm{v}_{\mathrm{i}}^{*}\right), \mathrm{i}=\mathrm{us}, \mathrm{eu}$, can be used to approximately describe the motion of the $\mathrm{i}$ along the path approaching $\left(\mathrm{h}_{2 \mathrm{i}}^{*}, \mathrm{H}_{\mathrm{i}}^{*}, \mathrm{v}_{\mathrm{i}}^{*}\right)$. The linearized path is governed by:

$$
\left[\begin{array}{l}
h_{2 i t+1}-h_{2 i}^{*} \\
H_{i t+1}-H_{i}^{*}
\end{array}\right]=F\left[\begin{array}{l}
h_{2 i t}-h_{2 i}^{*} \\
H_{i t}-H_{i}^{*}
\end{array}\right]+G_{i t}^{\frac{\sigma-1}{\sigma}}, F=\left[\begin{array}{ll}
f_{11} & f_{12} \\
f_{21} & f_{22}
\end{array}\right], G=\left[\begin{array}{l}
g_{11} \\
g_{21}
\end{array}\right],
$$

where $\mathrm{v}_{\mathrm{it}}=\left[\beta\left(1-\delta+\theta\left(\mathrm{h}_{2 \mathrm{i}}^{*}\right)^{1-\theta}\right)\right]^{-\mathrm{t}} \mathrm{v}_{\mathrm{i} 0}$ and $\mathrm{H}_{\mathrm{i} 0}=\mathrm{H}_{0} \in\left(\mathrm{H}_{\mathrm{us}}^{*}-\varepsilon, \mathrm{H}_{\mathrm{us}}^{*}+\varepsilon\right)$ is given, $\mathrm{i}=\mathrm{us}, \mathrm{eu}$ (see the Appendix for the elements of the matrices $F$ and G). One may think that the evolution of the US economy (the economy that is never constrained by labor market regulations and/or union ceilings) is approximately described by (17). Numerical examples show that (17) can be consistent with initial levels of market work and leisure lower than their steady-state levels $\left(\mathrm{h}_{2 \mathrm{us} 0}<\mathrm{h}_{2 \mathrm{us}}^{*}\right.$ and $\left.\mathrm{L}_{\mathrm{us} 0}<\mathrm{L}_{\mathrm{us}}^{*}\right)$ (see the Appendix), while domestic work tends to decline in the long run $\left(\mathrm{h}_{1 \mathrm{us} 0}>\mathrm{h}_{1 \mathrm{us}}^{*}\right)$.

Suppose again that preferences evolve in time, but assume now that labor supply is subject in the EU to some ceiling $\overline{\mathrm{h}}_{2},\left(\mathrm{~h}_{2 \text { eut }} \leq \overline{\mathrm{h}}_{2}\right)$ believed to be permanent by the economic agents and such that $\overline{\mathrm{h}}_{2} \in\left(\mathrm{h}_{2 \mathrm{eu}}^{*}-\varepsilon, \mathrm{h}_{2 \mathrm{eu}}^{*}+\varepsilon\right)$. Since $\mathrm{H}_{\mathrm{eu} 0}=\mathrm{H}_{0} \in\left(\mathrm{H}_{\mathrm{us}}^{*}-\varepsilon, \mathrm{H}_{\mathrm{us}}^{*}+\varepsilon\right)$, the constraint restricting labor supply is binding $\left(\mathrm{h}_{2 \text { eut }}=\overline{\mathrm{h}}\right)$, and the equilibrium path of the EU economy is governed by a system of difference equations in $\mathrm{H}_{\text {eut }}, \mathrm{Z}_{\text {eut }} \equiv \frac{\mathrm{x}_{\text {eut }}}{\mathrm{K}_{\text {eut }}}$ and $\mathrm{v}_{\text {eut }}$ consisting of (13)-(14) (with $\mathrm{h}_{2 \text { eut }+1}=\mathrm{h}_{2 \text { eut }}=\overline{\mathrm{h}}_{2}$ ) and of (see the Appendix for the derivation) 


$$
\Sigma\left(\mathrm{Z}_{\text {eut }+1}, \mathrm{v}_{\text {eut }+1}, \mathrm{Z}_{\text {eut }}, \mathrm{v}_{\text {eut }}\right)=\mathrm{Z}_{\text {eut }+1}\left(1-\delta+\overline{\mathrm{h}}_{2}^{1-\theta}-\mathrm{Z}_{\text {eut }}\left(1+\mathrm{v}_{\text {eut }+1}^{\frac{\sigma-1}{\sigma}}\right)-\mathrm{Z}_{\text {eut }} \beta\left(1-\delta+\theta \overline{\mathrm{h}}_{2}^{1-\theta}\right)\left(1+\mathrm{v}_{\text {eut }}^{\frac{\sigma-1}{\sigma}}\right)=0\right.
$$

An equilibrium path must also satisfy the transversality condition (see the Appendix)

$$
\lim _{t \rightarrow \infty} \beta^{t}\left[Z_{\text {eut }}\left(1+v_{\text {eut }}^{\frac{\sigma-1}{\sigma}}\right)\right]^{-1}=0
$$

A BGP can be characterized by setting $\mathrm{H}_{\text {eut }+1}=\mathrm{H}_{\text {eut }}=\mathrm{H}_{\mathrm{eu}}, \mathrm{Z}_{\text {eut }+1}=\mathrm{Z}_{\text {eut }}=\mathrm{Z}_{\mathrm{eu}}$ and $\mathrm{v}_{\text {eut }+1}=\mathrm{v}_{\text {eut }}=\mathrm{v}_{\mathrm{eu}}$ in (13)-(14) (with $\mathrm{h}_{2 \text { eut }+1}=\mathrm{h}_{2 \text { eut }}=\overline{\mathrm{h}}_{2}$ ) and in (18), Along a BGP, $\mathrm{Y}_{\text {eut }}$ grows at a rate $\mu_{\mathrm{eu}}=\beta\left(1-\delta+\theta \overline{\mathrm{h}}_{2}^{1-\theta}\right)-1>0$ (perpetual growth) $)^{14}$ and $\mathrm{L}_{\mathrm{eu}}=\mathrm{H}_{\mathrm{eu}}$. Moreover, one can check that it is possible to have only one triple $\left(\mathrm{H}_{\mathrm{eu}}, \mathrm{Z}_{\mathrm{eu}}, \mathrm{v}_{\mathrm{eu}}\right)$, say $\left(\mathrm{H}_{\mathrm{eu}}^{\prime \prime}, \mathrm{Z}_{\mathrm{eu}}, \mathrm{v}_{\mathrm{eu}}\right)$, which satisfies the system consisting of $\Psi()=$.0 , $\Omega()=$.0 and $\Sigma()=$.0 with $\mathrm{h}_{2 \mathrm{eut}+1}=\mathrm{h}_{2 \mathrm{eut}}=\overline{\mathrm{h}}_{2}, \mathrm{H}_{\mathrm{eut}+1}=\mathrm{H}_{\mathrm{eut}}=\mathrm{H}_{\mathrm{eu}}^{\prime \prime}, \mathrm{Z}_{\text {eut }+1}=\mathrm{Z}_{\mathrm{eut}}=\mathrm{Z}_{\mathrm{eu}}^{\prime \prime}$ and $\mathrm{v}_{\text {eut }+1}=\mathrm{v}_{\text {eut }}=\mathrm{v}_{\text {eu }}^{\prime \prime}$, where $\mathrm{H}_{\mathrm{eu}}^{\prime \prime}>\mathrm{H}_{\mathrm{us}}^{*}$ since $\mathrm{H}_{\mathrm{eu}}^{\prime \prime} \in\left(\mathrm{H}_{\mathrm{eu}}^{*}-\varepsilon, \mathrm{H}_{\mathrm{eu}}^{*}+\varepsilon\right)>\mathrm{H}_{\mathrm{us}}^{*}, \mathrm{Z}_{\mathrm{eu}}^{\prime \prime}=(1-\delta)(1-\beta)+(1-\beta \theta) \overline{\mathrm{h}}_{2}^{1-\theta}$ and $\mathrm{v}_{\mathrm{eu}}^{\prime \prime}=0 .{ }^{15}$

The system obtained by linearizing (13)-(14) (with $\mathrm{h}_{2 \text { eut }+1}=\mathrm{h}_{2 \text { eut }}=\overline{\mathrm{h}}_{2}$ ) and (18) around $\left(\mathrm{H}_{\mathrm{eu}}^{\prime \prime}, \mathrm{Z}_{\mathrm{eu}}^{\prime \prime}, \mathrm{v}_{\mathrm{eu}}\right)$ can be used to approximately describe the motion of the EU economy in a neighborhood of $\left(\mathrm{H}_{\mathrm{eu}}^{\prime \prime}, \mathrm{Z}_{\mathrm{eu}}^{\prime \prime}, \mathrm{v}_{\mathrm{eu}}^{\prime \prime}\right)$. The linearized path is governed by:

$$
\mathrm{H}_{\mathrm{eut}+1}-\mathrm{H}_{\mathrm{eu}}^{\prime \prime}=\left(\mathrm{H}_{\mathrm{eut}}-\mathrm{H}_{\mathrm{eu}}^{\prime \prime}\right)(1-\lambda)-\frac{(\sigma-1) \lambda\left(\mathrm{N}-\overline{\mathrm{h}}_{2}\right)}{\sigma m\left(\mathrm{H}_{\mathrm{eu}}^{\prime \prime}\right)} \mathrm{v}_{\mathrm{eut}}^{\frac{\sigma-1}{\sigma}}
$$

${ }^{14}$ Note that $\mu_{\mathrm{eu}}=\beta\left(1-\delta+\theta \overline{\mathrm{h}}_{2}^{1-\theta}\right)-1>0$ derives from the fact that $\mu_{\mathrm{eu}}^{*}=\beta\left(1-\delta+\theta\left(\mathrm{h}_{2 \mathrm{eu}}^{*}\right)^{1-\theta}\right)-1>0$, and from the assumption that $\overline{\mathrm{h}}_{2} \in\left(\mathrm{h}_{2 \mathrm{eu}}^{*}-\varepsilon, \mathrm{h}_{2 \mathrm{eu}}^{*}+\varepsilon\right)$.

${ }^{15}$ In the presence of a binding restriction limiting labor supply, a BGP consistent with perpetual growth must be unique since the units of market work are given and the units of domestic work tend asymptotically to zero, thus implying $\mathrm{v}_{\mathrm{eu}}^{\prime \prime}=0 \quad$ and $\quad \mathrm{L}_{\mathrm{eu}}^{\prime \prime}=\mathrm{N}-\overline{\mathrm{h}}_{2}$, entailing $\quad \mathrm{Z}_{\mathrm{eu}}^{\prime \prime}=(1-\delta)(1-\beta)+(1-\beta) \overline{\mathrm{h}}_{2}^{1-\theta} \quad$ and $\quad \mathrm{H}_{\mathrm{eu}}^{\prime \prime}=\mathrm{N}-\overline{\mathrm{h}}_{2}$. Note that $\mathrm{H}_{\mathrm{eu}}^{\prime \prime} \in\left(\mathrm{H}_{\mathrm{eu}}^{*}-\varepsilon, \mathrm{H}_{\mathrm{eu}}^{*}+\varepsilon\right)$ derives from the facts that $\mathrm{H}_{\mathrm{eu}}^{\prime \prime}=\mathrm{N}-\overline{\mathrm{h}}_{2}$ and $\mathrm{H}_{\mathrm{eu}}^{*}=\mathrm{N}-\mathrm{h}_{2 \mathrm{eu}}^{*}$, and from the assumption that $\overline{\mathrm{h}}_{2} \in\left(\mathrm{h}_{2 \mathrm{eu}}^{*}-\varepsilon, \mathrm{h}_{2 \mathrm{eu}}^{*}+\varepsilon\right)$. 


$$
\begin{gathered}
\mathrm{v}_{\text {eut }}=\left[\beta\left(1-\delta+\bar{\phi}_{2}^{1-\theta}\right)\right]^{-\mathrm{t}} \mathrm{v}_{\mathrm{eu} 0}, \\
\mathrm{Z}_{\mathrm{eut}+1}-\mathrm{Z}_{\mathrm{eu}}^{\prime \prime}=\left(\mathrm{Z}_{\mathrm{eut}}-\mathrm{Z}_{\mathrm{eu}}^{\prime \prime}\right)\left[\frac{\mathrm{Z}_{\mathrm{eu}}^{\prime \prime}+\beta\left(1-\delta+\overline{\phi_{2}^{1-\theta}}\right)}{1-\delta+\overline{\mathrm{h}}_{2}^{1-\theta}-\mathrm{Z}_{\mathrm{eu}}^{\prime \prime}}\right]+\frac{(\sigma-1)\left(\overline{\mathrm{h}}_{2}^{1-\theta}-\delta-\mathrm{Z}_{\mathrm{eu}}^{\prime \prime}\right)}{\sigma\left(1-\delta+\overline{\mathrm{h}}_{2}^{1-\theta}-\mathrm{Z}_{\mathrm{eu}}^{\prime \prime}\right)} \mathrm{v}_{\mathrm{eut}}^{\frac{\sigma-1}{\sigma}},
\end{gathered}
$$

where $\mathrm{H}_{\mathrm{eu} 0}=\mathrm{H}_{0} \in\left(\mathrm{H}_{\mathrm{us}}^{*}-\varepsilon, \mathrm{H}_{\mathrm{us}}^{*}+\varepsilon\right)$ is given.

By inspecting (22), one can easily check that $Z_{\text {eu }}^{\prime \prime}$ is unstable: any path such that $Z_{\text {eu } 0} \neq Z_{\text {eu }}^{\prime \prime}$ cannot be an equilibrium path since it is implosive or explosive and does not satisfy the boundary or the transversality condition. Thus, the unique equilibrium path of the EU economy for $\mathrm{t}<\mathrm{t}^{\#}$ must be characterized by $\mathrm{Z}_{\mathrm{eut}}=\mathrm{Z}_{\mathrm{eu}}^{\prime \prime} \forall \mathrm{t}<\mathrm{t}^{\#}$. In contrast, by inspecting (20)-(21) and by considering that $\mathrm{H}_{\mathrm{eu} 0}<\mathrm{H}_{\mathrm{eu}}^{\prime \prime}$, one can easily verify that along the equilibrium path $\mathrm{H}_{\text {eut }}$ tends to increase. Consistently, when in period $\mathrm{t}=\mathrm{t}^{\#}$ the restriction limiting labor supply in the EU is removed, the subjective value of leisure relative to consumption is higher in the EU than in the US: even if initially the preferences concerning the trade off between leisure and consumption were the same, these preferences diverged because in the interval $\left[0, \mathrm{t}^{\#}\right)$ the EU households' choices in matter of time use were constrained by the institutional barrier $\overline{\mathrm{h}}_{2}$.

Furthermore, the removal of the restrictions constraining labor supply in the EU may not be sufficient for permitting a convergence in preferences and hours of market hours between the EU and the US. As a matter of fact, it can be the case that $\mathrm{H}_{\mathrm{eut}}{ }^{\#} \in\left(\mathrm{H}_{\mathrm{eu}}^{*}-\varepsilon, \mathrm{H}_{\mathrm{eu}}^{*}+\varepsilon\right)$, thus allowing the EU economy to converge from $\mathrm{t}^{\#}$ on towards $\left(\mathrm{h}_{2 \mathrm{eu}}^{*}, \mathrm{H}_{\mathrm{eu}}^{*}, \mathrm{v}_{\mathrm{eu}}^{*}\right)$. Indeed, from $\mathrm{t}^{\#}$ on the equilibrium path of the EU economy is governed by (13)-(15). Hence, the system obtained by linearizing (13)-(15) in a neighborhood of $\left(\mathrm{h}_{2 \mathrm{eu}}^{*}, \mathrm{H}_{\mathrm{eu}}^{*}, \mathrm{v}_{\mathrm{eu}}^{*}\right)$ can be used to approximately describe the path followed by the EU from $\mathrm{t}^{\#}$ on. The linearized path is governed by (17), where $\mathrm{v}_{\text {eut }}=\left[\beta\left(1-\delta+\theta\left(\mathrm{h}_{2 \mathrm{eu}}^{*}\right)^{1-\theta}\right)\right]^{-\left(\mathrm{t}-\mathrm{t}^{\#}\right)} \mathrm{v}_{\text {eut }}{ }^{\#}, \quad \mathrm{t} \geq \mathrm{t}^{\#}, \quad$ and $\mathrm{H}_{\mathrm{eut}}^{\#} \in\left(\mathrm{H}_{\mathrm{eu}}^{*}-\varepsilon, \mathrm{H}_{\mathrm{eu}}^{*}+\varepsilon\right)$ is given. Numerical examples show that (17) can be consistent with an initial level of market work larger than its steady-state level $\left(\mathrm{h}_{2 \mathrm{eut}}{ }^{\#} \mathrm{~h}_{2 \mathrm{eu}}\right)$, and with an initial level of leisure lower than its steady-state level $\left(\mathrm{L}_{\text {eut }}{ }^{\#}<\mathrm{L}_{2 \mathrm{eu}}^{*}\right)$ (see the Appendix): even once that restrictions to labor 
supply due to regulation and/or unionization are not any longer binding, hours of market work per person in the EU may continue to decline.

The following proposition summarizes the main result obtained above:

Proposition 1. If preferences evolve in time and two economies, US and EU, share the same parameter values and initial condition, the removal in the EU of the restrictions that have constrained labor supply for a prolonged period of time may not allow this economy to converge to the same hours of market work per person of the US, which never was subject to such restrictions.

Proof: Consider that the equilibrium path of the US economy converges to $\left(\mathrm{h}_{2 \mathrm{us}}^{*}, \mathrm{H}_{\mathrm{us}}^{*}, \mathrm{v}_{\mathrm{us}}^{*}\right)$, while the equilibrium path of the EU economy converges from $\mathrm{t}^{\#}$ on to $\left(\mathrm{h}_{2 \mathrm{eu}}^{*}, \mathrm{H}_{\mathrm{eu}}^{*}, \mathrm{v}_{\mathrm{eu}}^{*}\right)$.

\section{2 $\underline{\text { Constant preferences }}$}

Suppose that social habits and norms concerning the use of time do not evolve $\left(\mathrm{H}_{\mathrm{t}}=\mathrm{H}_{0} \in\left(\mathrm{H}_{\mathrm{us}}^{*}-\varepsilon, \mathrm{H}_{\mathrm{us}}^{*}+\varepsilon\right) \forall \mathrm{t}\right)$ and that labor supply is never constrained by labor market regulations and/or union ceilings. In this case, the equilibrium path of the economy is governed by the system of difference equations in $\mathrm{h}_{2 \mathrm{t}}$ and $\mathrm{v}_{\mathrm{t}}$ consisting of (13) and (15) (with $\mathrm{H}_{\mathrm{t}+1}=\mathrm{H}_{\mathrm{t}}=\mathrm{H}_{0} \in\left(\mathrm{H}_{\mathrm{us}}^{*}-\varepsilon, \mathrm{H}_{\mathrm{us}}^{*}+\varepsilon\right)$ ). Together with (13) and (15), an equilibrium path must satisfy the transversality condition (16) (with $\mathrm{H}_{\mathrm{t}}=\mathrm{H}_{0}$ ).

A BGP with constant preferences can be characterized by setting $\mathrm{h}_{2 \mathrm{t}+1}=\mathrm{h}_{2 \mathrm{t}}=\mathrm{h}_{2}$ and $\mathrm{v}_{\mathrm{t}+1}=\mathrm{v}_{\mathrm{t}}=\mathrm{v}$ in (13) and (15) (with $\mathrm{H}_{\mathrm{t}+1}=\mathrm{H}_{\mathrm{t}}=\mathrm{H}_{0} \in\left(\mathrm{H}_{\mathrm{us}}^{*}-\varepsilon, \mathrm{H}_{\mathrm{us}}^{*}+\varepsilon\right)$ ). A BGP pair $\left(\mathrm{h}_{2}, \mathrm{v}\right)$ consistent with $\mu=\beta\left(1-\delta+\theta \mathrm{h}_{2}^{1-\theta}\right)-1>0$ must satisfy $\mathrm{v}=\mathrm{v}^{\circ}=0$ and $f\left(\mathrm{~h}_{2}\right)=(1-\delta)(1-\beta)+(1-\beta \theta) \mathrm{h}_{2}^{1-\theta}-\frac{(1-\theta)\left(\mathrm{N}-\mathrm{h}_{2}\right)}{m\left(\mathrm{H}_{0}\right) \mathrm{h}_{2}^{\theta}}=0$

Since $f>0$, there exists at most one value of $\mathrm{h}_{2}$, say $\mathrm{h}_{2}^{\circ}$, satisfying $f\left(\mathrm{~h}_{2}\right)=0$. Hence, the pair $\left(\mathrm{h}_{2}^{\circ}, \mathrm{v}^{\circ}\right)$ is unique. Moreover, since $\mathrm{H}_{0} \in\left(\mathrm{H}_{\mathrm{us}}^{*}-\varepsilon, \mathrm{H}_{\mathrm{us}}^{*}+\varepsilon\right)$ and $\mathrm{v}^{\circ}=\mathrm{v}_{\mathrm{us}}^{*}=0$, it is apparent that $\mathrm{h}_{2}^{\circ} \in\left(\mathrm{h}_{2 \mathrm{us}}^{*}-\varepsilon, \mathrm{h}_{2 \mathrm{us}}^{*}+\varepsilon\right)$, thus entailing $\mu^{\circ} \in\left(\mu_{\mathrm{us}}^{*}-\varepsilon, \mu_{\mathrm{us}}^{*}+\varepsilon\right)$ and $\mu^{\circ}>0$. 
The system obtained by linearizing (13) and (15) (with $\left.\mathrm{H}_{\mathrm{t}+1}=\mathrm{H}_{\mathrm{t}}=\mathrm{H}_{0}\right)$ around $\left(\mathrm{h}_{2}^{\circ}, \mathrm{v}^{\circ}\right)$ can be used to approximately describe the motion of the i economy in a neighborhood of $\left(\mathrm{h}_{2}^{\circ}, \mathrm{v}^{\circ}\right)$. The linearized path is governed by:

$$
\mathrm{h}_{2 \mathrm{it}+1}-\mathrm{h}_{2}^{\circ}=\left(\mathrm{h}_{2 \mathrm{it}}-\mathrm{h}_{2}^{\circ}\right) \mathrm{n}_{1}-\mathrm{n}_{2} \mathrm{v}_{\mathrm{it}}^{\frac{\sigma-1}{\sigma}}
$$

where $\mathrm{v}_{\text {it }}=\left[\beta\left(1-\delta+\theta\left(\mathrm{h}_{2}^{\circ}\right)^{1-\theta}\right)\right]^{-\mathrm{t}} \mathrm{v}_{\mathrm{i} 0}, \mathrm{i}=\mathrm{us}$,eu (see the Appendix for the values of $\mathrm{n}_{1}$ and $\mathrm{n}_{2}$ ). Assuming parameter values consistent with both $\beta\left[1-\delta+\theta\left(\mathrm{h}_{2}^{\circ}\right)^{1-\theta}\right]>1$ and $0<\mathrm{n}_{1}<1$, the pair $\left(\mathrm{h}_{2 \mathrm{it}}, \mathrm{v}_{\text {it }}\right)$ converges asymptotically to $\left(\mathrm{h}_{2}^{\circ}, \mathrm{v}^{\circ}\right)$ for any possible initial pair $\left(\mathrm{h}_{2 \mathrm{i} 0}, \mathrm{v}_{\mathrm{i} 0}\right)$ in a neighborhood of it (see the Appendix). One may think that--if preferences were constant--the evolution of the US economy (the economy that is never constrained by labor market regulations and/or union ceilings) would be approximately described by (23).

Suppose again that social norms and habits do not change over time (and that - thereforepreferences are time invariant), but assume now that the EU labor supply is subject to some ceiling $\overline{\mathrm{h}}_{2}$ $\left(\mathrm{h}_{2 \mathrm{eu}} \leq \overline{\mathrm{h}}_{2}\right)$ believed to be permanent by the economic agents and such that $\overline{\mathrm{h}}_{2} \in\left(\mathrm{h}_{2 \mathrm{eu}}^{*}-\varepsilon, \mathrm{h}_{2 \mathrm{eu}}^{*}+\varepsilon\right)$. Since $\mathrm{H}_{0} \in\left(\mathrm{H}_{\text {us }}^{*}-\varepsilon, \mathrm{H}_{\text {us }}^{*}+\varepsilon\right)$, the constraint restricting labor supply is binding $\left(\mathrm{h}_{2 \text { eut }}=\overline{\mathrm{h}}_{2}<\mathrm{h}_{2}^{\circ}\right)$, and for $\mathrm{t}<\mathrm{t}$ the equilibrium path of the economy is governed by the system of difference equations in $Z_{\text {eut }}$ and $v_{t}$ consisting of (13) (with $\mathrm{H}_{\text {eut }+1}=\mathrm{H}_{\text {eut }}=\mathrm{H}_{0}$ and $\mathrm{h}_{2 \text { eut }+1}=\mathrm{h}_{2 \text { eut }}=\overline{\mathrm{h}}_{2}$ ) and (18). Together with (13) and (18), an equilibrium path must satisfy the transversality condition (19).

A BGP can be characterized by setting $Z_{\text {eut }+1}=Z_{\text {eut }}=Z_{\text {eu }}^{\prime \prime}$ and $v_{\text {eut }+1}=v_{\text {eut }}=v_{e u}^{\prime \prime}$ in (13) (with $\mathrm{H}_{\text {eut }+1}=\mathrm{H}_{\text {eut }}=\mathrm{H}_{0}$ and $\left.\mathrm{h}_{2 \text { eut }+1}=\mathrm{h}_{2 \text { eut }}=\overline{\mathrm{h}}_{2}\right)$ and (18). Again, note that the pair $\left(\mathrm{Z}_{\mathrm{eu}}^{\prime \prime}, \mathrm{v}_{\text {eu }}^{\prime \prime}\right)$ is unique and that along the BGP $\mathrm{Y}_{\text {eut }}$ grows at a rate $\mu_{\mathrm{eu}}=\beta\left(1-\delta+\theta \overline{\mathrm{h}}_{2}^{1-\theta}\right)-1>0$. The system (21)-(22) can be used to approximately describe the motion of the EU economy in a neighborhood of $\left(\mathrm{Z}_{\mathrm{eu}}^{\prime \prime}, \mathrm{v}_{\mathrm{eu}}\right)$.

As in period $\mathrm{t}^{\#}$ the restriction limiting labor supply in the EU is removed, the equilibrium path of the EU economy is governed by the same system of difference equations in $h_{2 t}$ and $v_{t}$ which would govern the 
US economy if preferences were constant, namely by the system consisting of (13) and (15) (with $\left.\mathrm{H}_{\mathrm{t}+1}=\mathrm{H}_{\mathrm{t}}=\mathrm{H}_{0} \in\left(\mathrm{H}_{\mathrm{us}}^{*}-\varepsilon, \mathrm{H}_{\mathrm{us}}^{*}+\varepsilon\right)\right)$. Hence, also the EU economy--which by assumption has the same parameter values of the US economy--would converge from $\mathrm{t}^{\#}$ on to the unique steady-state pair $\left(\mathrm{h}_{2}^{\circ}, \mathrm{v}^{\circ}\right)$. This proves the following proposition:

Proposition 2. If preferences were time-invariant and two economies, US and EU, share the same parameter values and initial condition $\mathrm{H}_{\mathrm{us} 0}=\mathrm{H}_{\mathrm{eu} 0}=\mathrm{H}_{0}$, the removal in the $\mathrm{EU}$ of the restrictions that have constrained labor supply for a prolonged period of time would allow this economy to converge to the same units of market work per person of the US economy, which never was subject to such restrictions.

\section{LABOR TAXES AND THEIR EFFECT ON THE DIFFERENCE IN WORKED HOURS PER PERSON}

Also in this section it is assumed that two countries, US and EU, share the same parameter values and the same initial condition $\mathrm{H}_{0}$. However, the two countries are assumed to differ because labor income is taxed more heavily in the EU than in the US. Again, the analysis is conducted both under the hypothesis that preferences concerning the trade off between leisure and consumption evolve in time and under the alternative hypothesis that they do not change.

To incorporate the existence of labor taxation, I rewrite the period budget constraint of the representative household as:

$$
\mathrm{K}_{\mathrm{t}+1}+\mathrm{C}_{\mathrm{t}} \leq \mathrm{K}_{\mathrm{t}}(1-\delta)+\pi_{\mathrm{t}}+\mathrm{R}_{\mathrm{t}} \mathrm{K}_{\mathrm{t}}+(1-\tau) \mathrm{W}_{\mathrm{t}} \mathrm{h}_{2 \mathrm{t}}+\mathrm{T}_{\mathrm{t}}, 0<\delta<1,0<\tau<1, \mathrm{~K}_{0} \text { given, }
$$

where $\tau$ is the tax rate and $T_{t}$ are the government transfers received by each household in $t$. By assuming that taxes are entirely returned to households in the form of transfers, one has:

$$
\tau \mathrm{W}_{\mathrm{t}} \mathrm{h}_{2 \mathrm{t}}=\mathrm{T}_{\mathrm{t}}
$$

\subsection{Evolving preferences}

Assume that social habits and norms evolve in time according to (9). In this case, the equilibrium path of the economy must satisfy the system of difference equations in $\mathrm{h}_{2 \mathrm{t}}, \mathrm{H}_{\mathrm{t}}$ and $\mathrm{v}_{\mathrm{t}}$ consisting of (13)-(14) and (see the Appendix) 


$$
\begin{aligned}
\Theta\left(\mathrm{h}_{2 \mathrm{t}+1}, \mathrm{H}_{\mathrm{t}+1}, \mathrm{v}_{\mathrm{t}+1}, \mathrm{~h}_{2 \mathrm{t}}, \mathrm{H}_{\mathrm{t}}, \mathrm{v}_{\mathrm{t}}, \tau_{\mathrm{i}}\right)=\frac{\mathrm{h}_{2 \mathrm{t}}^{\theta} m\left(\mathrm{H}_{\mathrm{t}}\right)\left[1-\delta+\mathrm{h}_{2 \mathrm{t}}^{1-\theta}\right]}{(1-\theta)\left(1-\tau_{\mathrm{i}}\right) L\left(\mathrm{~h}_{2 \mathrm{t}}, \mathrm{H}_{\mathrm{t}}, \mathrm{v}_{\mathrm{t}}\right)}-\left(1+\mathrm{v}_{\mathrm{t}}^{\frac{\sigma-1}{\sigma}}\right)^{-1}- \\
\quad-\frac{\mathrm{h}_{2 \mathrm{t}+1}^{\theta} m\left(\mathrm{H}_{\mathrm{t}+1}\right) \beta\left[1-\delta+\theta \mathrm{h}_{2 \mathrm{t}+1}^{1-\theta}\right]}{(1-\theta)\left(1-\tau_{\mathrm{i}}\right) L\left(\mathrm{~h}_{2 \mathrm{t}+1}, \mathrm{H}_{\mathrm{t}+1}, \mathrm{v}_{\mathrm{t}+1}\right)}=0, \mathrm{i}=\mathrm{us, \text {eu. }}
\end{aligned}
$$

Together with (13)-(14) and (26), an equilibrium path must satisfy the following transversality condition:

$$
\lim _{\mathrm{t} \rightarrow \infty} \beta^{\mathrm{t}} \frac{m\left(\mathrm{H}_{\mathrm{t}}\right) \mathrm{h}_{2 \mathrm{t}}^{\theta}}{(1-\theta)\left(1-\tau_{\mathrm{i}}\right) L\left(\mathrm{~h}_{2 \mathrm{t}}, \mathrm{H}_{\mathrm{t}}, \mathrm{v}_{\mathrm{t}}\right)}=0, \mathrm{i}=\mathrm{eu}, \mathrm{us} .
$$

Suppose that there exists a unique BGP triple, say $\left(\mathrm{h}_{2 \mathrm{i}}, \mathrm{H}_{\mathrm{i}}^{\bullet}, \mathrm{v}_{\mathrm{i}}^{\bullet}\right), \mathrm{i}=\mathrm{us}$, eu, such that: i) it satisfies the system consisting of $\Psi()=0,. \Omega()=$.0 and $\Theta()=$.0 with $\mathrm{h}_{2 \mathrm{t}+1}=\mathrm{h}_{2 \mathrm{t}}=\mathrm{h}_{2 \mathrm{i}}^{\bullet}, \quad \mathrm{H}_{\mathrm{t}+1}=\mathrm{H}_{\mathrm{t}}=\mathrm{H}_{\mathrm{i}}^{\bullet} \quad$ and $\mathrm{v}_{\mathrm{t}+1}=\mathrm{v}_{\mathrm{t}}=\mathrm{v}_{\mathrm{i}}^{\bullet}$, ii) it is consistent with $\mu_{\mathrm{i}}^{\bullet}=\beta\left(1-\delta+\theta\left(\mathrm{h}_{2 \mathrm{i}}^{\bullet}\right)^{1-\theta}\right)-1>0$ (perpetual growth), and iii) it is locally stable. It is easy to check that $\mathrm{v}_{\mathrm{i}}^{\bullet}=0$, and that $\mathrm{h}_{2 \mathrm{i}}^{\bullet}$ and $\mathrm{H}_{\mathrm{i}}^{\bullet}$ are those values of $\mathrm{h}_{2}$ and $\mathrm{H}$ which satisfy both $q\left(\mathrm{~h}_{2}, \mathrm{H}, \tau_{\mathrm{i}}\right)=(1-\delta)(1-\beta)+(1-\beta \theta) \mathrm{h}_{2}^{1-\theta}-\frac{(1-\theta)\left(1-\tau_{\mathrm{i}}\right)\left(\mathrm{N}-\mathrm{h}_{2}\right)}{m(\mathrm{H}) \mathrm{h}_{2}^{\theta}}=0$ and $\mathrm{H}=\mathrm{L}=\mathrm{N}-\mathrm{h}_{2}$ (see Figure 3). Moreover, one can easily verify that $\tau_{\mathrm{eu}}>\tau_{\mathrm{us}}$ (the tax wedge on labor is higher in the EU than in the US) implies that $\mathrm{H}_{\mathrm{us}}^{\bullet}<\mathrm{H}_{\mathrm{eu}}^{\bullet}$ and $\mathrm{h}_{2 \mathrm{us}}^{\bullet}>\mathrm{h}_{2 \mathrm{eu}}^{\bullet}$ (see the Appendix), thus entailing $\alpha_{\mathrm{us}}^{\bullet}<\alpha_{\mathrm{eu}}^{\bullet}$ and $\mu_{\mathrm{us}}^{\bullet}>\mu_{\text {eu }}^{\bullet}$ : along a BGP, the subjective value of leisure relative to consumption is higher in the EU, where labor income is taxed more heavily, while the hours of market hours per person are higher in the US, where labor income is taxed less heavily.

The system obtained by linearizing (13)-(14) and (26) in a neighborhood of $\left(\mathrm{h}_{2 \mathrm{i}}, \mathrm{H}_{\mathrm{i}}^{\bullet}, \mathrm{v}_{\mathrm{i}}^{\bullet}\right), \mathrm{i}=\mathrm{us}, \mathrm{eu}$, can be used to approximately describe the motion of the $\mathrm{i}$ economy along the path approaching $\left(\mathrm{h}_{2 \mathrm{i}}^{\bullet}, \mathrm{H}_{\mathrm{i}}^{\bullet}, \mathrm{v}_{\mathrm{i}}^{\mathbf{i}}\right)$. The linearized path is governed by:

$$
\left[\begin{array}{l}
\mathrm{h}_{2 \mathrm{it}+1}-\mathrm{h}_{2 \mathrm{i}}^{\bullet} \\
\mathrm{H}_{\mathrm{it}+1}-\mathrm{H}_{\mathrm{i}}^{\bullet}
\end{array}\right]=\mathrm{B}\left[\begin{array}{l}
\mathrm{h}_{2 \mathrm{it}}-\mathrm{h}_{2 \mathrm{i}}^{\bullet} \\
\mathrm{H}_{\mathrm{it}}-\mathrm{H}_{\mathrm{i}}^{\bullet}
\end{array}\right]+\mathrm{Pv}_{\mathrm{it}}^{\frac{\sigma-1}{\sigma}}, \mathrm{B}=\left[\begin{array}{ll}
\mathrm{b}_{11} & \mathrm{~b}_{12} \\
\mathrm{~b}_{21} & \mathrm{~b}_{22}
\end{array}\right] \mathrm{P}=\left[\begin{array}{l}
\mathrm{p}_{11} \\
\mathrm{p}_{21}
\end{array}\right],
$$

where $\mathrm{v}_{\mathrm{it}}=\left[\beta\left(1-\delta+\theta\left(\mathrm{h}_{2 \mathrm{i}}^{\bullet}\right)^{1-\theta}\right)\right]^{-\mathrm{t}} \mathrm{v}_{\mathrm{i} 0}$ and $\mathrm{H}_{\mathrm{us} 0}=\mathrm{H}_{\mathrm{eu} 0}=\mathrm{H}_{0}$ is given, $\mathrm{i}=\mathrm{us}$, eu (see the Appendix for the elements of the matrices B and P). Numerical examples show that (28) can be consistent with an initial level of market work lower (higher) than its steady-state level in the country where labor is taxed less (more) 
heavily ( $\mathrm{h}_{2 \text { us } 0}<\mathrm{h}_{2 \mathrm{us}}^{\bullet}$ and $\mathrm{h}_{2 \mathrm{eu} 0}>\mathrm{h}_{2 \mathrm{eu}}^{\bullet}$ ), with an initial level of leisure lower than its steady-state level in both countries $\mathrm{L}_{\text {us } 0}<\mathrm{L}_{\text {us }}^{\bullet}$ and $\mathrm{L}_{\mathrm{eu} 0}<\mathrm{L}_{\mathrm{eu}}^{\bullet}$ ), and with an initial level of domestic work higher than its steady-state level in both countries $\left(\mathrm{h}_{1 \mathrm{us} 0}>\mathrm{h}_{1 \mathrm{us}}^{\bullet}\right.$ and $\left.\mathrm{h}_{1 \mathrm{eu} 0}>\mathrm{h}_{1 \mathrm{eu}}^{\bullet}\right)$ (see the Appendix). In particular, it is worth to emphasize that the model may account for an increasing divergence in hours of market work per person in the presence of an unchanged inter-country differential in tax rates.

\subsection{Constant preferences}

Suppose that social habits and norms do not evolve in time $\left(\mathrm{H}_{\mathrm{t}}=\mathrm{H}_{0} \forall \mathrm{t}\right.$, where $\left.\mathrm{H}_{\mathrm{us}}^{\bullet}<\mathrm{H}_{0}<\mathrm{H}_{\mathrm{eu}}^{\bullet}\right)$. In this case, the equilibrium path of the economy is governed by the system of difference equations in $h_{2 t}$ and $v_{t}$ consisting of (13) and (26) (with $\mathrm{H}_{\mathrm{t}+1}=\mathrm{H}_{\mathrm{t}}=\mathrm{H}_{0}$ ). Together with (13) and (26), an equilibrium path must satisfy the transversality condition (27) (with $\mathrm{H}_{\mathrm{t}}=\mathrm{H}_{0}$ ).

Assume that there exists a pair of BGP values of $\left(h_{2}, v\right)$, say $\left(h_{2 i}^{\circ}, v_{i}^{\circ 0}\right), i=u s, e u$, such that: i) it satisfies the system consisting of $\Psi()=$.0 and $\Theta()=$.0 (with $\mathrm{H}_{\mathrm{t}+1}=\mathrm{H}_{\mathrm{t}}=\mathrm{H}_{0}$ ), ii) it is consistent with $\mu_{\mathrm{i}}^{\circ \circ}=\beta\left(1-\delta+\theta\left(\mathrm{h}_{2 \mathrm{i}}^{\circ \circ}\right)^{1-\theta}\right)-1>0$ (perpetual growth), and iii) it is locally stable. Again, it is easy to check that $\mathrm{v}_{\mathrm{i}}^{\circ 0}=0$, and that $\mathrm{h}_{2 \mathrm{i}}^{\circ \circ}$ is that value of $\mathrm{h}_{2}$ satisfying $q\left(\mathrm{~h}_{2}, \mathrm{H}, \tau_{\mathrm{i}}\right)=0$ with $\mathrm{H}=\mathrm{H}_{0}$ (see Figure 3 ). Note that since $\frac{\partial q\left(\mathrm{~h}_{2}, \mathrm{H}, \tau_{\mathrm{i}}\right)}{\partial \mathrm{h}_{2}}>0$ there may exist at most one value of $\mathrm{h}_{2}$ satisfying $q\left(\mathrm{~h}_{2}, \mathrm{H}, \tau_{\mathrm{i}}\right)=0$ with $\mathrm{H}=\mathrm{H}_{0}$. Hence, the BGP pair $\left(\mathrm{h}_{2 \mathrm{i}}^{\circ}, \mathrm{v}_{\mathrm{i}}^{\circ}\right)$ is unique.

Moreover, the system obtained by linearizing (13) and (26) (with $\left.\mathrm{H}_{\mathrm{t}+1}=\mathrm{H}_{\mathrm{t}}=\mathrm{H}_{0}\right)$ around $\left(\mathrm{h}_{2 \mathrm{i}}^{\circ}, \mathrm{v}_{\mathrm{i}}^{\circ}\right.$ ) can be used to approximately describe the motion of the i economy in a neighborhood of it, $\mathrm{i}=\mathrm{us}$, eu. The linearized path is governed by:

$$
\mathrm{h}_{2 \mathrm{t}+1}-\mathrm{h}_{2 \mathrm{i}}^{\circ}=\left(\mathrm{h}_{2 \mathrm{t}}-\mathrm{h}_{2 \mathrm{i}}^{\circ}\right) z_{1}-\mathrm{z}_{2} \mathrm{v}_{\mathrm{t}}^{\frac{\sigma-1}{\sigma}}, \mathrm{i}=\mathrm{us}, \mathrm{eu},
$$


where $\mathrm{v}_{\mathrm{t}}=\left[\beta\left(1-\delta+\theta\left(\mathrm{h}_{2 \mathrm{i}}^{\circ}\right)^{1-\theta}\right)\right]^{-\mathrm{t}} \mathrm{v}_{0}$ (see the Appendix for the values of $\mathrm{z}_{1}$ and $\mathrm{z}_{2}$ ). Assuming parameter values consistent with both $\beta\left[1-\delta+\theta\left(\mathrm{h}_{2 \mathrm{i}}^{\circ}\right)^{1-\theta}\right]>1$ and $0<\mathrm{z}_{1}<1$, the pair $\left(\mathrm{h}_{2 \mathrm{t}}, \mathrm{v}_{\mathrm{t}}\right)$ converges asymptotically to $\left(\mathrm{h}_{2 \mathrm{i}}^{\circ}, \stackrel{\circ}{\circ} \mathrm{v}_{\mathrm{i}}^{\circ}\right)$ for any possible initial pair $\left(\mathrm{h}_{20}, \mathrm{v}_{0}\right)$ in a neighborhood of it (see the Appendix).

Finally, since $\frac{\partial q\left(\mathrm{~h}_{2}, \mathrm{H}, \tau_{\mathrm{i}}\right)}{\partial \mathrm{h}_{2}}>0, \frac{\partial q\left(\mathrm{~h}_{2}, \mathrm{H}, \tau_{\mathrm{i}}\right)}{\partial \tau_{\mathrm{i}}}>0$ and $\tau_{\mathrm{us}}<\tau_{\mathrm{eu}}$, the implicit function theorem implies that $\mathrm{h}_{2 \mathrm{us}}^{\circ \circ}>\mathrm{h}_{2 \mathrm{eu}}^{\circ 0}$ : even assuming constant preferences, hours of market work per person are permanently higher in the US than in the EU. For $\mathrm{H}_{\mathrm{us}}^{\bullet}<\mathrm{H}_{0}<\mathrm{H}_{\mathrm{eu}}^{\bullet}$, one can also prove the following proposition:

Proposition 3 The differential in the steady-state level of market work per person between the EU, which is the economy that taxes labor income more heavily, and the US, which is the economy that taxes labor income less heavily, is larger when one accounts for the evolution of preferences over time than when one assumes that preferences are time invariant.

Proof: Since $\mathrm{H}_{\mathrm{us}}^{\bullet}<\mathrm{H}_{0}<\mathrm{H}_{\mathrm{eu}}^{\bullet}, \frac{\partial q\left(\mathrm{~h}_{2}, \mathrm{H}, \tau_{\mathrm{i}}\right)}{\partial \mathrm{h}_{2}}>0$ and $\frac{\partial q\left(\mathrm{~h}_{2}, \mathrm{H}, \tau_{\mathrm{i}}\right)}{\partial \mathrm{H}}>0$, the implicit function theorem implies both that $\mathrm{h}_{2 \text { us }}^{\circ \circ}<\mathrm{h}_{2 \text { us }}^{\bullet}$ and that $\mathrm{h}_{2 \mathrm{eu}}^{\circ \circ}>\mathrm{h}_{2 \mathrm{eu}}^{\bullet}$ (see Figure 3 ).

In other words, the same difference in tax rate can generate in the long run a larger inter-country differential in hours of market work per person if the subjective value of leisure relative to consumption evolves in time responding to past social experiences concerning leisure and worked hours. 


\section{FIGURE 3}

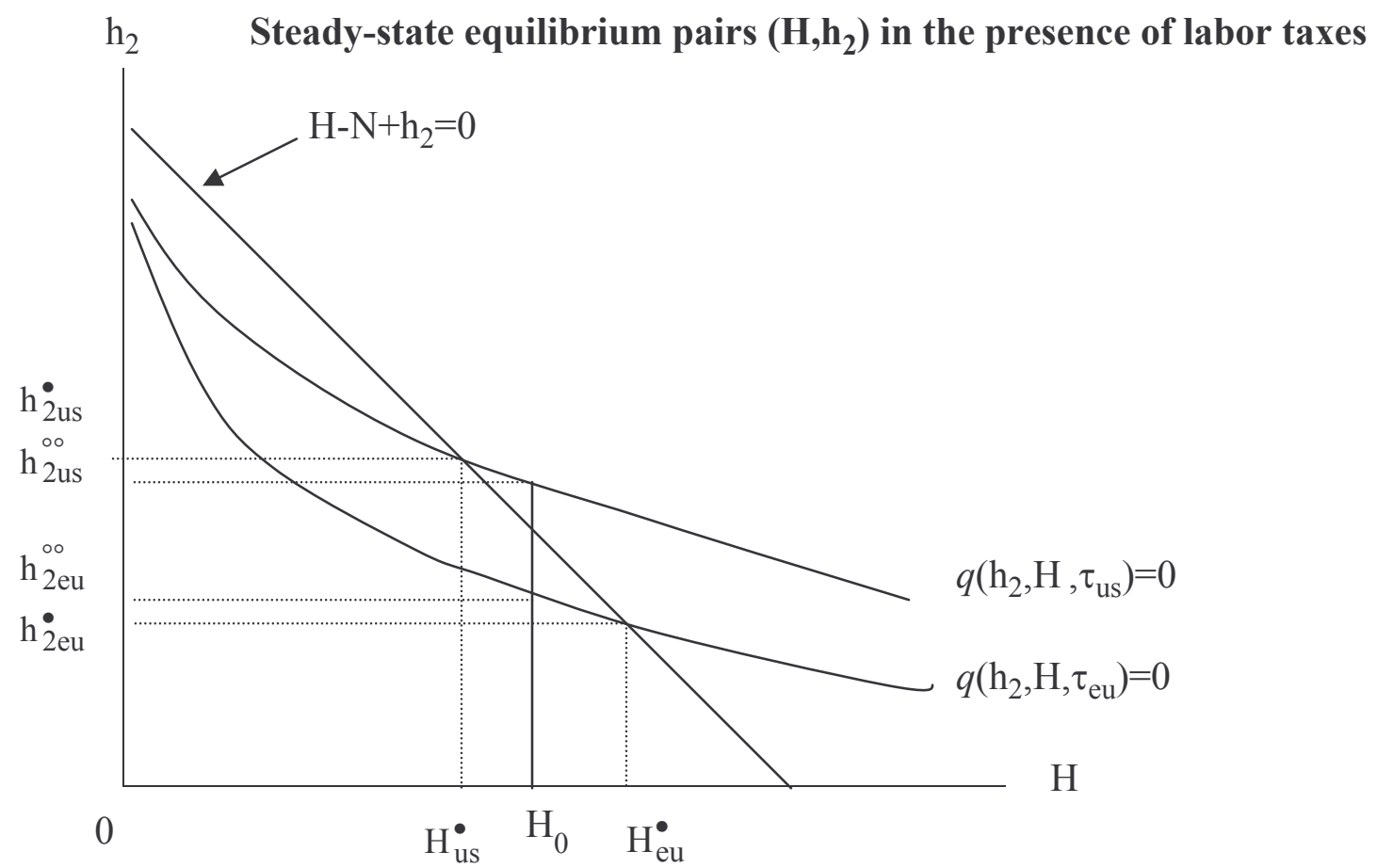

\section{CONCLUSIONS}

In Germany, as in France or in Italy, most employees consider the possibility of enjoying one-month (or longer) paid vacation per year as a sort of non-negotiable right. The increase in pay for which they would be willing to accept shorter vacations is probably very high. One may state that nowadays the fact that an employee has four (or five)-week long vacation is part of the European way of life, an undisputed social norm. Its status is perceived to be similar to the right for every European citizen to have access for free to basic health care. Obviously, fifty years ago things were very different: the present social norm in matter of paid vacation has emerged as a result of a long process and it is not immutable. Similarly, it is likely that most American employees would not be willing to renounce to the consumer standards that they can afford by devoting more time to market activities than their European counterparts in order to enjoy longer vacations. Also international surveys seem to confirm that the attitudes toward work differ between the US and Western Europe, with Americans showing more devotion to market work than Europeans. Is it correct to conclude that--as far as the use of time is concerned--cultures are different on the two sides of the Atlantic?

Alesina et al. (2005) argue that simply invoking different cultures to explain why Europeans are currently devoting less time to market activities than Americans is unconvincing, since this explanation should account for the fact that culture started diverging in the early 1970s across the Atlantic. This point is 
stressed also by Tullio Jappelli in his comment to Freeman and Schettkat (2005): "for cultural factors to be able to account for such diverging trends one cannot rely on cross-sectional evidence. Rather, one should be able to show that preference for market work has changed over time in either the US, Europe, or both." (p. 45). In this paper, I have modeled the hypothesis that permanent differences in individual attitudes toward work can emerge between two countries as a result of a period in which only one of the two countries was subject to labor-market regulations and unionization constraining labor supply, or as a by-product of an intercountry difference in tax rates.

The model is consistent with the continuation of a falling trend in hours of market work per person in the economy subject to binding restrictions to labor supply, even after the removal of these barriers. As a consequence, this removal does not allow this economy to converge to the same level of market work per person of the economy which never was subject to such restrictions. By contrast, if preferences were assumed to be time-invariant, a regime shift lifting the barriers to labor supply would allow the economy thus deregulated to converge to the same worked hours per person of the economy which never was subject to such restrictions. Furthermore, the model is consistent with an increasing cross-country divergence in worked hours per person even when the inter-country difference in labor tax rates remains unchanged. Finally, the model shows that the differential in the steady-state level of market work between the economy that taxes labor income more heavily and the economy that taxes labor income less heavily is larger when one accounts for the evolution of preferences over time than when one assumes that preferences are time invariant.

This paper models the hypothesis that households' work preferences tend to change in response to variations in social habits concerning time allocation, whose evolution depends on past experiences in matter of time use. As seen in Section 2, there is some evidence that corroborates this hypothesis. However, future research should provide more systematic empirical support to it. Moreover, the model predicts that institutions and policies which have a temporary influence on individual choices regarding time use can have long lasting effects because of their persistent impact on social norms and habits. Again, future research should systematically ascertain whether these predictions are consistent with the relevant facts. 


\section{Appendix}

\section{Derivation of the system (13)-(15)}

One can solve the firms' problem by maximizing (2) with respect to $\mathrm{h}_{2 \mathrm{t}}$ and $\mathrm{K}_{\mathrm{t}}$, thus obtaining:

$$
\begin{gathered}
\mathrm{W}_{\mathrm{t}}=(1-\theta) \mathrm{K}_{\mathrm{t}} \mathrm{h}_{2 \mathrm{t}}^{-\theta}=(1-\theta) \mathrm{Y}_{\mathrm{t}} \mathrm{h}_{2 \mathrm{t}}^{-1}, \\
\mathrm{R}_{\mathrm{t}}=\theta \mathrm{h}_{2 \mathrm{t}}^{1-\theta}=\theta \mathrm{Y}_{\mathrm{t}} \mathrm{K}_{\mathrm{t}}^{-1} .
\end{gathered}
$$

Moreover, one can solve the households' problem by maximizing $\sum_{\mathrm{t}=0}^{\infty} \beta^{\mathrm{t}}\left\{\frac{\sigma}{(\sigma-1)} \ln \left(\mathrm{x}_{\mathrm{t}}^{\frac{\sigma-1}{\sigma}}+\mathrm{h}_{1 \mathrm{t}}^{\frac{\sigma-1}{\sigma}}\right)+\alpha_{\mathrm{t}} \ln \left(\mathrm{N}-\mathrm{h}_{1 \mathrm{t}}-\mathrm{h}_{2 \mathrm{t}}\right)+\zeta_{\mathrm{t}}\left[(1-\delta) \mathrm{K}_{\mathrm{t}}+\mathrm{W}_{\mathrm{t}} \mathrm{h}_{2 \mathrm{t}}+\mathrm{R}_{\mathrm{t}} \mathrm{K}_{\mathrm{t}}-\mathrm{x}_{\mathrm{t}}-\mathrm{K}_{\mathrm{t}+1}\right]\right\}$ with respect to $\mathrm{x}_{\mathrm{t}}$, $\mathrm{h}_{1 \mathrm{t}}, \mathrm{h}_{2 \mathrm{t}}, \mathrm{K}_{\mathrm{t}+1}$ and the Lagrangean multiplier $\zeta_{\mathrm{t}}$, and then by eliminating $\zeta_{\mathrm{t}}$, thus obtaining:

$$
\begin{gathered}
\left(\mathrm{N}-\mathrm{v}_{\mathrm{t}} \mathrm{x}_{\mathrm{t}}-\mathrm{h}_{2 \mathrm{t}}\right) \mathrm{v}_{\mathrm{t}}^{\frac{-1}{\sigma}}=\left(1+\mathrm{v}_{\mathrm{t}}^{\frac{\sigma-1}{\sigma}}\right) \alpha_{\mathrm{t}} \mathrm{x}_{\mathrm{t}}, \mathrm{v}_{\mathrm{t}} \equiv \frac{\mathrm{h}_{1 \mathrm{t}}}{\mathrm{x}_{\mathrm{t}}}, \\
\left(\mathrm{N}-\mathrm{v}_{\mathrm{t}} \mathrm{x}_{\mathrm{t}}-\mathrm{h}_{2 \mathrm{t}}\right) \mathrm{W}_{\mathrm{t}}=\left(1+\mathrm{v}_{\mathrm{t}}^{\frac{\sigma-1}{\sigma}}\right) \alpha_{\mathrm{t}} \mathrm{x}_{\mathrm{t}}, \\
\left(\begin{array}{c}
\mathrm{K}_{\mathrm{t}+1}=(1-\delta) \mathrm{K}_{\mathrm{t}}+\mathrm{W}_{\mathrm{t}} \mathrm{h}_{2 \mathrm{t}}+\mathrm{R}_{\mathrm{t}} \mathrm{K}_{\mathrm{t}}-\mathrm{x}_{\mathrm{t}}, \\
1+\mathrm{v}_{\mathrm{t}+1}^{\frac{\sigma}{\sigma}}
\end{array} \mathrm{x}_{\mathrm{t}+1}=\beta\left(1+\mathrm{v}_{\mathrm{t}}^{\frac{\sigma-1}{\sigma}}\right) \mathrm{x}_{\mathrm{t}}\left(1-\delta+\mathrm{R}_{\mathrm{t}+1}\right) .\right.
\end{gathered}
$$

By using (A3), one can obtain:

$$
\begin{gathered}
\mathrm{x}_{\mathrm{t}}=\left(\mathrm{N}-\mathrm{h}_{2 \mathrm{t}}\right) \mathrm{v}_{\mathrm{t}}^{\frac{-1}{\sigma}}\left[\alpha_{\mathrm{t}}\left(1+\mathrm{v}_{\mathrm{t}}^{\frac{\sigma-1}{\sigma}}\right)+\mathrm{v}_{\mathrm{t}}^{\frac{\sigma-1}{\sigma}}\right]^{-1}, \\
\mathrm{~h}_{1 \mathrm{t}}=\mathrm{x}_{\mathrm{t}} \mathrm{v}_{\mathrm{t}}=\left(\mathrm{N}-\mathrm{h}_{2 \mathrm{t}}\right) \mathrm{v}_{\mathrm{t}}^{\frac{\sigma-1}{\sigma}}\left[\alpha_{\mathrm{t}}\left(1+\mathrm{v}_{\mathrm{t}}^{\frac{\sigma-1}{\sigma}}\right)_{\left.+\mathrm{v}_{\mathrm{t}} \frac{\sigma-1}{\sigma}\right]^{-1},}\right. \\
\mathrm{L}_{\mathrm{t}}=\mathrm{N}-\mathrm{v}_{\mathrm{t}} \mathrm{x}_{\mathrm{t}}-\mathrm{h}_{2 \mathrm{t}}=\left(\mathrm{N}-\mathrm{h}_{2 \mathrm{t}}\right) \alpha_{\mathrm{t}}\left(1+\mathrm{v}_{\mathrm{t}} \frac{\sigma-1}{\sigma}\right)\left[\alpha_{\mathrm{t}}\left(1+\mathrm{v}_{\mathrm{t}}^{\frac{\sigma-1}{\sigma}}\right)+\mathrm{v}_{\mathrm{t}}^{\frac{\sigma-1}{\sigma}}\right]^{-1} .
\end{gathered}
$$

By using (8), (A2), (A7) and (A8), one can rewrite (A6) as (13).

Moreover, by using (A9), one can rewrite (9) as (14). 
Finally, by using (A4) and (A9), one can obtain:

$$
\mathrm{x}_{\mathrm{t}}=\left(\mathrm{N}-\mathrm{h}_{2 \mathrm{t}}\right) \mathrm{W}_{\mathrm{t}}\left[\alpha_{\mathrm{t}}\left(1+\mathrm{v}_{\mathrm{t}}^{\frac{\sigma-1}{\sigma}}\right)+\mathrm{v}_{\mathrm{t}}^{\frac{\sigma-1}{\sigma}}\right]^{-1}
$$

Together with (A1) and (A2), (A10) allows us to rewrite (A5) as

$$
\frac{\mathrm{K}_{\mathrm{t}+1}}{\mathrm{~K}_{\mathrm{t}}}=1-\delta+\mathrm{h}_{2 \mathrm{t}}^{1-\theta}-\left(\mathrm{N}-\mathrm{h}_{2 \mathrm{t}}\right)(1-\theta) \mathrm{h}_{2 \mathrm{t}}^{-\theta}\left[\alpha_{\mathrm{t}}\left(1+\mathrm{v}_{\mathrm{t}}^{\frac{\sigma-1}{\sigma}}\right)+\mathrm{v}_{\mathrm{t}}^{\frac{\sigma-1}{\sigma}}\right]^{-1} .
$$

By using (8), (A1), (A9), (A10) and (A11), one can rewrite (A6) as (15).

\section{Derivation of (16)}

The transversality condition that an optimal path governed by (13)-(15) must satisfy is:

$$
\lim _{t \rightarrow \infty} \beta^{t} \zeta_{t} K_{t}=0
$$

Since along an optimal path $\zeta_{\mathrm{t}}=\frac{\alpha_{\mathrm{t}}}{\mathrm{L}_{\mathrm{t}} \mathrm{W}_{\mathrm{t}}}$, one can use (8), (A1) and (A9) to rewrite (A12) as (16).

3. Existence of two steady-state triples $\left(\mathrm{h}_{2 \mathrm{eu}}^{*}, \mathrm{H}_{\mathrm{eu}}^{*}, \mathrm{v}_{\mathrm{eu}}^{*}\right)$ and $\left(\mathrm{h}_{2 \mathrm{us}}^{*}, \mathrm{H}_{\mathrm{us}}^{*}, \mathrm{v}_{\mathrm{us}}^{*}\right)$

Given (A1) and (A10), if $\lim _{\mathrm{t} \rightarrow \infty} \mu_{\mathrm{t}}=\mu>0$, then $\lim _{\mathrm{t} \rightarrow \infty} \frac{\mathrm{x}_{\mathrm{t}+1}-\mathrm{x}_{\mathrm{t}}}{\mathrm{x}_{\mathrm{t}}}=\mu>0$, which in its turn entails $\lim _{\mathrm{t} \rightarrow \infty} \mathrm{v}_{\mathrm{t}}=\mathrm{v}=0$ since $\lim _{\mathrm{t} \rightarrow \infty} \mathrm{h}_{1 \mathrm{t}}=\mathrm{h}_{1} \leq \mathrm{N}$. Hence, a steady-state triple $\left(\mathrm{h}_{2}, \mathrm{H}, \mathrm{v}\right)$ consistent with $\mu>0$ must satisfy $\mathrm{v}=0$, $s\left(\mathrm{~h}_{2}, \mathrm{H}\right)=(1-\delta)(1-\beta)+(1-\beta \theta) \mathrm{h}_{2}^{1-\theta}-\frac{(1-\theta)\left(\mathrm{N}-\mathrm{h}_{2}\right)}{m(\mathrm{H}) \mathrm{h}_{2}^{\theta}}=0$ and $g\left(\mathrm{~h}_{2}, \mathrm{H}\right)=\mathrm{H}-\mathrm{N}+\mathrm{h}_{2}=0$. Since both $\left.\frac{d \mathrm{~h}_{2}}{d \mathrm{H}}\right|_{s\left(\mathrm{~h}_{2}, \mathrm{H}\right)=0}<0$ and $\left.\frac{d \mathrm{~h}_{2}}{d \mathrm{H}}\right|_{g\left(\mathrm{~h}_{2}, \mathrm{H}\right)=0}<0$, it is possible to have more than one pair $\left(\mathrm{h}_{2}, \mathrm{H}\right)$, say $\left(\mathrm{h}_{2 \mathrm{eu}}^{*}, \mathrm{H}_{\mathrm{eu}}^{*}, \mathrm{v}_{\mathrm{eu}}^{*}\right)$ and $\left(\mathrm{h}_{2 \mathrm{us}}^{*}, \mathrm{H}_{\mathrm{us}}^{*}, \mathrm{v}_{\mathrm{us}}^{*}\right)$, satisfying $s()=$.0 and $g()=$.0 . Moreover, $\left.\frac{d \mathrm{~h}_{2}}{d \mathrm{H}}\right|_{s\left(\mathrm{~h}_{2}, \mathrm{H}\right)=0}<0\left(\right.$ or $\left.\left.\frac{d \mathrm{~h}_{2}}{d \mathrm{H}}\right|_{g\left(\mathrm{~h}_{2}, \mathrm{H}\right)=0}<0\right)$ implies that if $\mathrm{H}_{\mathrm{eu}}^{*}>\mathrm{H}_{\mathrm{us}}^{*}$, then it is necessarily the case that $\mathrm{h}_{2 \mathrm{eu}}^{*}<\mathrm{h}_{2 \mathrm{us}}^{*}$. As a numerical example, let $m\left(\mathrm{H}_{\mathrm{t}}\right)=4.5093884\left(10^{-7}\right) \mathrm{H}_{\mathrm{t}}^{3.6312411}, \mathrm{~N}=100, \beta=0.95, \delta=0.05, \theta=0.35, \lambda=0.01$ and $\sigma=1,5$. Given these values, one has $\mathrm{h}_{2 \mathrm{us}}^{*}=30.5, \mathrm{H}_{\mathrm{us}}^{*}=69.5\left(\right.$ entailing $\left.\alpha_{\mathrm{us}}^{*}=2.2019552\right)$, and $\mathrm{h}_{2 \mathrm{eu}}^{*}=24.5, \mathrm{H}_{\mathrm{eu}}^{*}=75.5\left(\right.$ entailing $\left.\alpha_{\mathrm{eu}}^{*}=2.9743753\right)$.

\section{Elements of the matrices $F$ and $G$}

By linearizing (13)-(15) in a neighborhood of $\left(\mathrm{h}_{2 \mathrm{i}}^{*}, \mathrm{H}_{\mathrm{i}}^{*}, \mathrm{v}_{\mathrm{i}}^{*}\right)$, one can obtain $(17)$, where $\mathrm{f}_{21}=-\lambda, \mathrm{f}_{22}=1-\lambda$, 


$$
\begin{aligned}
& \mathrm{f}_{11}=F_{1}\left(\mathrm{~h}_{2 \mathrm{i}}^{*}, \mathrm{H}_{\mathrm{i}}^{*}\right)=\frac{m\left(\mathrm{H}_{\mathrm{i}}^{*}\right)\left\{\mathrm{N}\left[\theta(1-\delta)\left(\mathrm{h}_{2 \mathrm{i}}^{*}\right)^{\theta-1}+1\right]+(1-\delta)(1-\theta)\left(\mathrm{h}_{2 \mathrm{i}}^{*}\right)^{\theta}\right\}+\lambda\left(\mathrm{N}-\mathrm{h}_{2 \mathrm{i}}^{*}\right) m^{\prime} \beta\left[1-\delta+\left(\mathrm{h}_{2 \mathrm{i}}^{*}\right)^{1-\theta}\right]}{\beta m\left(\mathrm{H}_{\mathrm{i}}^{*}\right)\left\{\mathrm{N}\left[\theta(1-\delta)\left(\mathrm{h}_{2 \mathrm{i}}^{*}\right)^{1-\theta}+\theta\right]+(1-\delta)(1-\theta)\left(\mathrm{h}_{2 \mathrm{i}}^{*}\right)^{\theta}\right\}}, \\
& \mathrm{f}_{12}=F_{2}\left(\mathrm{~h}_{2 \mathrm{i}}^{*}, \mathrm{H}_{\mathrm{i}}^{*}\right)=\frac{\left(\mathrm{N}-\mathrm{h}_{2 \mathrm{i}}^{*}\right) m^{\prime}\left(\mathrm{h}_{2 \mathrm{i}}^{*}\right)^{\theta}\left\{1-\delta+\left(\mathrm{h}_{2 \mathrm{i}}^{*}\right)^{1-\theta}-(1-\lambda) \beta\left[1-\delta+\theta\left(\mathrm{h}_{2 \mathrm{i}}^{*}\right)^{1-\theta}\right]\right\}}{\beta m\left(\mathrm{H}_{\mathrm{i}}^{*}\right)\left\{\mathrm{N}\left[\theta(1-\delta)\left(\mathrm{h}_{2 \mathrm{i}}^{*}\right)^{1-\theta}+\theta\right]+(1-\delta)(1-\theta)\left(\mathrm{h}_{2 \mathrm{i}}^{*}\right)^{\theta}\right\}}, \\
& \mathrm{g}_{11}=G_{1}\left(\mathrm{~h}_{2 \mathrm{i}}^{*}, \mathrm{H}_{\mathrm{i}}^{*}\right)=\frac{\left\{m\left(\mathrm{H}_{\mathrm{i}}^{*}\right)\left[\left(\mathrm{N}-\mathrm{h}_{2 \mathrm{i}}^{*}\right)(1-\theta)\left(\mathrm{h}_{2 \mathrm{i}}^{*}\right)^{-\theta}-\delta+\left(\mathrm{h}_{2 \mathrm{i}}^{*}\right)^{1-\theta}\right]+m^{\prime} \beta\left(\mathrm{N}-\mathrm{h}_{2 \mathrm{i}}^{*}\right) \lambda\left[1-\delta+\theta\left(\mathrm{h}_{2 \mathrm{i}}^{*}\right)^{1-\theta}\right]\right\}}{\left[\left(\mathrm{N}-\mathrm{h}_{2 \mathrm{i}}^{*}\right)(\sigma-1)\right]^{-1}\left(\mathrm{~h}_{2 \mathrm{i}}^{*}\right)^{-\theta} \sigma \beta\left[m\left(\mathrm{H}_{\mathrm{i}}^{*}\right)\right]^{2}\left\{\mathrm{~N}\left[\theta(1-\delta)\left(\mathrm{h}_{2 \mathrm{i}}^{*}\right)^{1-\theta}+\theta\right]+(1-\delta)(1-\theta)\left(\mathrm{h}_{2 \mathrm{i}}^{*}\right)^{\theta}\right.}, \\
& \mathrm{g}_{21}=G_{2}\left(\mathrm{~h}_{2 \mathrm{i}}^{*}, \mathrm{H}_{\mathrm{i}}^{*}\right)=-\frac{\left(\mathrm{N}-\mathrm{h}_{2 \mathrm{i}}^{*}\right)(\sigma-1) \lambda}{\sigma m\left(\mathrm{H}_{\mathrm{i}}^{*}\right)} .
\end{aligned}
$$

\section{Dynamics of the i economy along the linearized path governed by (17)}

Solving (17), one obtains:

$$
\begin{aligned}
\mathrm{h}_{2 \mathrm{it}}-\mathrm{h}_{2 \mathrm{i}}^{*}= & \mathrm{e}_{11}\left\{\left[\frac{\left(\mathrm{h}_{2 \mathrm{i} 0}-\mathrm{h}_{2 \mathrm{i}}^{*}\right)-\mathrm{e}_{12}\left(\mathrm{H}_{\mathrm{i} 0}-\mathrm{H}_{\mathrm{i}}^{*}\right)}{\mathrm{e}_{11}-\mathrm{e}_{12}}\right] \chi_{1}^{\mathrm{t}}+\left(\mathrm{g}_{11} \mathrm{u}_{11}+\mathrm{g}_{21} \mathrm{u}_{12}\right) \mathrm{v}_{\mathrm{i} 0}^{\frac{\sigma-1}{\sigma}} \sum_{\mathrm{j}=0}^{\mathrm{t}-1} \chi_{1}^{\mathrm{j}} \chi_{3}^{\frac{(\sigma-1)(\mathrm{t}-1-\mathrm{j})}{\sigma}}\right\}+ \\
& +\mathrm{e}_{12}\left\{\left[\frac{\mathrm{e}_{11}\left(\mathrm{H}_{\mathrm{i} 0}-\mathrm{H}_{\mathrm{i}}^{*}\right)-\left(\mathrm{h}_{2 \mathrm{i} 0}-\mathrm{h}_{2 \mathrm{i}}^{*}\right)}{\mathrm{e}_{11}-\mathrm{e}_{12}}\right] \chi_{2}^{\mathrm{t}}+\left(\mathrm{g}_{11} \mathrm{u}_{21}+\mathrm{g}_{21} \mathrm{u}_{22}\right) \mathrm{v}_{\mathrm{i} 0}^{\frac{\sigma-1}{\sigma}} \sum_{\mathrm{j}=0}^{\mathrm{t}-1} \chi_{2}^{\mathrm{j}} \frac{(\sigma-1)(\mathrm{t}-1-\mathrm{j})}{\sigma}\right\}, \mathrm{i}=\mathrm{us}, \text { eu, }
\end{aligned}
$$

$$
\begin{aligned}
\mathrm{H}_{\mathrm{it}}-\mathrm{H}_{\mathrm{i}}^{*}=\left[\frac{\left(\mathrm{h}_{2 \mathrm{i} 0}-\mathrm{h}_{2 \mathrm{i}}^{*}\right)-\mathrm{e}_{12}\left(\mathrm{H}_{\mathrm{i} 0}-\mathrm{H}_{\mathrm{i}}^{*}\right)}{\mathrm{e}_{11}-\mathrm{e}_{12}}\right] \chi_{1}^{\mathrm{t}}+\left(\mathrm{g}_{11} \mathrm{u}_{11}+\mathrm{g}_{21} \mathrm{u}_{12}\right) \mathrm{v}_{\mathrm{i} 0}^{\frac{\sigma-1}{\sigma}} \sum_{\mathrm{j}=0}^{\mathrm{t}-1} \chi_{1}^{\mathrm{j}} \chi_{3}^{\frac{(\sigma-1)(\mathrm{t}-1-\mathrm{j})}{\sigma}}+ \\
+\left[\frac{\mathrm{e}_{11}\left(\mathrm{H}_{\mathrm{i} 0}-\mathrm{H}_{\mathrm{i}}^{*}\right)-\left(\mathrm{h}_{2 \mathrm{i} 0}-\mathrm{h}_{2 \mathrm{i}}^{*}\right)}{\mathrm{e}_{11}-\mathrm{e}_{12}}\right] \chi_{2}^{\mathrm{t}}+\left(\mathrm{g}_{11} \mathrm{u}_{21}+\mathrm{g}_{21} \mathrm{u}_{22}\right) \mathrm{v}_{\mathrm{i} 0}^{\frac{\sigma-1}{\sigma}} \sum_{\mathrm{j}=0}^{\mathrm{t}-1} \chi_{2}^{\mathrm{j}} \chi_{3}^{\frac{(\sigma-1)(\mathrm{t}-1-\mathrm{j})}{\sigma}}, \mathrm{i}=\mathrm{us}, \mathrm{eu},
\end{aligned}
$$

where $\chi_{1}$ and $\chi_{2}$ are the eigenvalues of $\mathrm{F}, \chi_{3}=\left[\beta\left(1-\delta+\theta\left(\mathrm{h}_{2 \mathrm{i}}^{*}\right)^{1-\theta}\right]^{-1}, \mathrm{E}=\left[\begin{array}{cc}\mathrm{e}_{11} & \mathrm{e}_{12} \\ 1 & 1\end{array}\right]\right.$ is the matrix of the eigenvectors of $F, E^{-1}=\left[\begin{array}{ll}u_{11} & u_{12} \\ u_{21} & u_{22}\end{array}\right]$ is the inverse of matrix $E$, and $H_{u s 0}=H_{e u 0}=H_{0} \in\left(H_{i}^{*}-\varepsilon, H_{i}^{*}+\varepsilon\right)$ is given. Notice that $\chi_{1}, \chi_{2}=\frac{\mathrm{f}_{11}+\mathrm{f}_{22}}{2} \pm\left[\left(\frac{\mathrm{f}_{11}+\mathrm{f}_{22}}{2}\right)^{2}-\mathrm{f}_{11} \mathrm{f}_{22}+\mathrm{f}_{12} \mathrm{f}_{21}\right]^{\frac{1}{2}}, \mathrm{e}_{11}=\frac{1-\lambda-\chi_{1}}{\lambda}$ and $\mathrm{e}_{12}=\frac{1-\lambda-\chi_{2}}{\lambda}$.

As a numerical example, let $m\left(\mathrm{H}_{\mathrm{t}}\right)=4.5093884\left(10^{-7}\right) \mathrm{H}_{\mathrm{t}}^{3.6312411}, \mathrm{~N}=100, \beta=0.95, \delta=0.05, \theta=0.35, \lambda=0.01$ and $\sigma=1.5$. Given these values, one has: $\mathrm{h}_{2 \mathrm{us}}^{*}=30.5, \mathrm{~h}_{1 \mathrm{us}}^{*}=0, \mathrm{H}_{\mathrm{us}}^{*}=\mathrm{L}_{\mathrm{us}}^{*}=69.5, \quad$ and $\mathrm{h}_{2 \mathrm{eu}}^{*}=24.5, \quad \mathrm{~h}_{1 \mathrm{eu}}^{*}=0$, $\mathrm{H}_{\mathrm{eu}}^{*}=\mathrm{L}_{\mathrm{eu}}^{*}=75.5$. In a neighborhood of $\left(\mathrm{h}_{2 \mathrm{us}}^{*}, \mathrm{H}_{\mathrm{us}}^{*}, \mathrm{v}_{\mathrm{us}}^{*}\right)$, one has: $\chi_{1}=0.986517, \chi_{2}=0.3306454, \chi_{3}=0.2519779$, 
thus guaranteeing asymptotic convergence. Moreover, if $\mathrm{H}_{\mathrm{us} 0}=\mathrm{H}_{0}=64.5$, one may have $\mathrm{h}_{2 \mathrm{us} 0}=28.5<\mathrm{h}_{2 \mathrm{us}}^{*}$, $\mathrm{h}_{1 \mathrm{us} 0}=h_{1}\left(\mathrm{~h}_{2 \mathrm{us} 0}, \mathrm{H}_{\mathrm{us} 0}, \mathrm{v}_{\mathrm{us} 0}\right)=9.886226>\mathrm{h}_{1 \text { us }}^{*}$ and $\mathrm{L}_{\mathrm{us} 0}=L\left(\mathrm{~h}_{2 \mathrm{us} 0}, \mathrm{H}_{\mathrm{us} 0}, \mathrm{v}_{\mathrm{us} 0}\right)=61.613774<\mathrm{L}_{\mathrm{us}}^{*}$. In a neighborhood of $\left(\mathrm{h}_{2 \mathrm{eu}}^{*}, \mathrm{H}_{\mathrm{eu}}^{*}, \mathrm{v}_{\mathrm{eu}}^{*}\right)$, one has: $\chi_{1}=0.9867064, \chi_{2}=0.3752286, \chi_{3}=0.2807654$, thus guaranteeing asymptotic convergence. Moreover, if $\mathrm{H}_{\text {eut }^{\#}}=72.5, \quad$ one hay have $\mathrm{h}_{2 \mathrm{eut}}{ }^{\#}=26.5>\mathrm{h}_{2 \mathrm{eu}}^{*}$, $\mathrm{h}_{1 \text { eut }}{ }^{\#}=h_{1}\left(\mathrm{~h}_{2 \text { eut }}^{\#}, \mathrm{H}_{\text {eut }^{\#}}, \mathrm{v}_{\text {eut }}^{\#}\right)=10.806303>\mathrm{h}_{1 \text { eu }}^{*}$ and $\mathrm{L}_{\text {eut }}^{\#}=L\left(\mathrm{~h}_{2 \text { eut }}^{\#}, \mathrm{H}_{\text {eut }}^{\#}, \mathrm{v}_{\text {eut }}^{\#}\right)=62.693697<\mathrm{L}_{\text {eu }}^{*}$.

\section{Derivation of (18)}

Given (A1) and (A2) (with $\left.\mathrm{h}_{2 \text { eut }}=\overline{\mathrm{h}}_{2}\right)$, (A5) can be rewritten as

$$
\frac{\mathrm{K}_{\text {eut }+1}}{\mathrm{~K}_{\text {eut }}}=1-\delta+\overline{\mathrm{h}}_{2}^{1-\theta}-\mathrm{Z}_{\text {eut }} .
$$

In its turn (A19) can be used - together with (A2) - to rewrite (A6) as (18).

\section{Derivation of (19)}

The transversality condition that an optimal path governed by (13)-(14) (with $\mathrm{h}_{2 \text { eut }+1}=\mathrm{h}_{2 \text { eut }}=\overline{\mathrm{h}}_{2}$ ) and (18) must satisfy is given by (A12). Since along an optimal path $\zeta_{\mathrm{t}}=\left[\mathrm{x} \text { eut }\left(1+\mathrm{v}_{\text {eut }}^{\frac{\sigma-1}{\sigma}}\right)\right]^{-1}$, one can rewrite (A12) as (19).

8. Values of $n_{1}$ and $n_{2}$ in (23)

By linearizing (13) and (15) (with $\left.\mathrm{H}_{\mathrm{t}+1}=\mathrm{H}_{\mathrm{t}}=\mathrm{H}_{0}\right)$ around $\left(\mathrm{h}_{2}^{\circ}, \mathrm{v}^{\circ}\right)$, one can obtain (23), where $\mathrm{n}_{1}=F_{1}\left(\mathrm{~h}_{2}^{\circ}, \mathrm{H}_{0}\right)$ (see (A13)) and $\mathrm{n}_{2}=G_{1}\left(\mathrm{~h}_{2}^{\circ}, \mathrm{H}_{0}\right)($ see $(\mathrm{A} 15))$.

9. Numerical example showing that there exist parameter values consistent with both $\beta\left[1-\delta+\theta\left(\mathrm{h}_{2}^{\circ}\right)^{1-\theta}\right]>1$ and $0<n_{1}<1$

As a numerical example, let $\mathrm{N}=100, \beta=0.95, \delta=0.05, \theta=0.35, \lambda=0.01, \sigma=1.5$ and $\mathrm{H}_{0}=69.5$. Given these values, one has: $\mathrm{h}_{2}^{\circ}=30.5, \mathrm{v}^{\circ}=0, \beta\left[1-\delta+\theta\left(\mathrm{h}_{2}^{\circ}\right)^{1-\theta}\right]=3.9686016$ and $\mathrm{n}_{1}=0.3271624$.

10. Derivation of (26)

In the presence of taxation, one can solve the households' problem by maximizing $\sum_{\mathrm{t}=0}^{\infty} \beta^{\mathrm{t}}\left\{\frac{\sigma}{(\sigma-1)} \ln \left(\mathrm{x}_{\mathrm{t}}^{\frac{\sigma-1}{\sigma}}+\mathrm{h}_{1 \mathrm{t}}^{\frac{\sigma-1}{\sigma}}\right)+\alpha_{\mathrm{t}} \ln \left(\mathrm{N}-\mathrm{h}_{1 \mathrm{t}}-\mathrm{h}_{2 \mathrm{t}}\right)+\zeta_{\mathrm{t}}\left[(1-\delta) \mathrm{K}_{\mathrm{t}}+\left(1-\tau_{\mathrm{i}}\right) \mathrm{W}_{\mathrm{t}} \mathrm{h}_{2 \mathrm{t}}+\mathrm{R}_{\mathrm{t}} \mathrm{K}_{\mathrm{t}}-\mathrm{x}_{\mathrm{t}}-\mathrm{K}_{\mathrm{t}+1}\right]\right\}, \mathrm{i}=$ us,eu, with 
respect to $\mathrm{x}_{\mathrm{t}}, \mathrm{h}_{1 \mathrm{t}}, \mathrm{h}_{2 \mathrm{t}}, \mathrm{K}_{\mathrm{t}+1}$ and the Lagrangean multiplier $\zeta_{\mathrm{t}}$, and then by eliminating $\zeta_{\mathrm{t}}$, thus obtaining (A3), (A5), (A6) and

$$
\left(\mathrm{N}-\mathrm{v}_{\mathrm{t}} \mathrm{x}_{\mathrm{t}}-\mathrm{h}_{2 \mathrm{t}}\right) \mathrm{W}_{\mathrm{t}}\left(1-\tau_{\mathrm{i}}\right)=\left(1+\mathrm{v}_{\mathrm{t}}^{\frac{\sigma-1}{\sigma}}\right) \alpha_{\mathrm{t}} \mathrm{x}_{\mathrm{t}}, \mathrm{i}=\mathrm{us}, \mathrm{eu} .
$$

By using (A9) and (A20), one can obtain:

$$
\mathrm{x}_{\mathrm{t}}=\left(\mathrm{N}-\mathrm{h}_{2 \mathrm{t}}\right) \mathrm{W}_{\mathrm{t}}\left(1-\tau_{\mathrm{i}}\right)\left[\alpha_{\mathrm{t}}\left(1+\mathrm{v}_{\mathrm{t}}^{\frac{\sigma-1}{\sigma}}\right)+\mathrm{v}_{\mathrm{t}}^{\frac{\sigma-1}{\sigma}}\right]^{-1}, \mathrm{i}=\mathrm{us}, \text { eu. }
$$

Together with (A1) and (A2), (A21) allows us to rewrite (A5) as

$$
\frac{\mathrm{K}_{\mathrm{t}+1}}{\mathrm{~K}_{\mathrm{t}}}=1-\delta+\mathrm{h}_{2 \mathrm{t}}^{1-\theta}-\left(\mathrm{N}-\mathrm{h}_{2 \mathrm{t}}\right)\left(1-\tau_{\mathrm{i}}\right)(1-\theta) \mathrm{h}_{2 \mathrm{t}}^{-\theta}\left[\alpha_{\mathrm{t}}\left(1+\mathrm{v}_{\mathrm{t}}^{\frac{\sigma-1}{\sigma}}\right)+\mathrm{v}_{\mathrm{t}}^{\frac{\sigma-1}{\sigma}}\right]^{-1}, \mathrm{i}=\mathrm{us}, \mathrm{eu} .
$$

By using (8), (A1), (A9), (A21) and (A22), one can rewrite (A6) as (26).

\section{Derivation of (27)}

Since along an optimal path $\zeta_{\mathrm{t}}=\frac{\alpha_{\mathrm{t}}}{\mathrm{L}_{\mathrm{t}}\left(1-\tau_{\mathrm{i}}\right) \mathrm{W}_{\mathrm{t}}}$, i=us,eu, one can use (8), (A1) and (A9) to rewrite (A12) as (27).

12. Proof that $\mathrm{H}_{\mathrm{us}}^{\bullet}<\mathrm{H}_{\mathrm{eu}}^{\bullet}$ and $\mathrm{h}_{2 \mathrm{us}}^{\bullet}>\mathrm{h}_{2 \mathrm{eu}}^{\bullet}$

The existence of a unique pair $\mathrm{H}_{\mathrm{i}}^{\bullet}$ and $\mathrm{h}_{2 \mathrm{i}}^{\bullet}, \mathrm{i}=\mathrm{us}$,eu, which satisfies the system consisting of $q\left(\mathrm{~h}_{2}, \mathrm{H}, \tau_{\mathrm{i}}\right)=0$ and $g\left(\mathrm{~h}_{2}, \mathrm{H}\right)=\mathrm{H}-\mathrm{N}+\mathrm{h}_{2}=0$, implies that

$$
\left.\frac{d \mathrm{~h}_{2}}{d \mathrm{H}}\right|_{g\left(\mathrm{~h}_{2}, \mathrm{H}\right)=0}<\left.\frac{d \mathrm{~h}_{2}}{d \mathrm{H}}\right|_{q\left(\mathrm{~h}_{2}, \mathrm{H}, \tau_{\mathrm{i}}\right)=0}<0 \text { at } \mathrm{H}=\mathrm{H}_{\mathrm{i}}^{\bullet} \text { and } \mathrm{h}_{2}=\mathrm{h}_{2 \mathrm{i}}^{\bullet} \text {, us,eu. }
$$

One can also check that

$$
\left.\frac{d \mathrm{~h}_{2}}{d \tau_{\mathrm{i}}}\right|_{q\left(\mathrm{~h}_{2}, \mathrm{H}, \tau_{\mathrm{i}}\right)=0}<0, \mathrm{i}=\mathrm{us}, \mathrm{eu} .
$$

It is apparent that (A23) and (A24) - together with $\tau_{\mathrm{eu}}>\tau_{\mathrm{us}}{ }^{- \text {-imply that }} \mathrm{H}_{\mathrm{us}}^{\bullet}<\mathrm{H}_{\mathrm{eu}}^{\bullet}$ and $\mathrm{h}_{2 \mathrm{us}}^{\bullet}>\mathrm{h}_{2 \mathrm{eu}}^{\bullet}$. As a numerical example, let $m\left(\mathrm{H}_{\mathrm{t}}\right)=0.0754504+0.0214678 \mathrm{H}_{\mathrm{t}}, \quad \mathrm{N}=100, \quad \beta=0.95, \quad \delta=0.05, \quad \theta=0.35, \quad \lambda=0.1, \quad \sigma=1,5, \quad \tau_{\mathrm{us}}=0.3$, $\tau_{\mathrm{eu}}=0.4179614$. Given these values, one has: $\mathrm{h}_{2 \mathrm{us}}^{\bullet}=30, \mathrm{H}_{\mathrm{us}}^{\bullet}=70$ (entailing $\alpha_{\mathrm{us}}^{\bullet}=1.5782014$ ), and $\mathrm{h}_{2 \mathrm{eu}}^{\bullet}=25$, $\mathrm{H}_{\mathrm{eu}}^{\bullet}=75$ (entailing $\alpha_{\mathrm{eu}}^{\bullet}=1.6855354$ ). 


\section{Elements of the matrices $B$ and $P$}

By linearizing (13)-(14) and (26) in a neighborhood of $\left(\mathrm{h}_{2 \mathrm{i}}^{\bullet}, \mathrm{H}_{\dot{\mathrm{i}}}^{\bullet}, \mathrm{v}_{\mathrm{i}}^{\bullet}\right)$, one can obtain (28), where $\mathrm{b}_{11}=F_{1}\left(\mathrm{~h}_{2 \mathrm{i}}, \mathrm{H}_{\mathrm{i}}^{\bullet}\right)$ (see (A13)), $\mathrm{b}_{12}=F_{2}\left(\mathrm{~h}_{2 \mathrm{i}}^{\bullet}, \mathrm{H}_{\mathrm{i}}^{\bullet}\right)(\operatorname{see}(\mathrm{A} 14)), \mathrm{b}_{21}=-\lambda, \mathrm{b}_{22}=1-\lambda, \mathrm{p}_{21}=G_{2}\left(\mathrm{~h}_{2}^{\bullet}, \mathrm{H}_{\mathrm{i}}^{\bullet}\right)($ see (A16)) and

$$
\mathrm{p}_{11}=\frac{\left\{m\left(\mathrm{H}_{\mathrm{i}}^{\bullet}\right)\left[\left(\mathrm{N}-\mathrm{h}_{2 \mathrm{i}}^{\bullet}\right)(1-\theta)\left(1-\tau_{\mathrm{i}}\right)\left(\mathrm{h}_{2 \mathrm{i}}^{\bullet}\right)^{-\theta}-\delta+\left(\mathrm{h}_{2 \mathrm{i}}\right)^{1-\theta}\right]+m^{\prime} \beta\left(\mathrm{N}-\mathrm{h}_{2 \mathrm{i}}^{\bullet}\right) \lambda\left[1-\delta+\theta\left(\mathrm{h}_{2 \mathrm{i}}^{\bullet}\right)^{1-\theta}\right]\right\}}{\left[\left(\mathrm{N}-\mathrm{h}_{2 \mathrm{i}}^{\bullet}\right)(\sigma-1)\right]^{-1}\left(\mathrm{~h}_{2 \mathrm{i}}^{\bullet}\right)^{-\theta} \sigma \beta\left[m\left(\mathrm{H}_{\mathrm{i}}^{\bullet}\right)\right]^{2}\left\{\mathrm{~N}\left[\theta(1-\delta)\left(\mathrm{h}_{2 \mathrm{i}}\right)^{1-\theta}+\theta\right]+(1-\delta)(1-\theta)\left(\mathrm{h}_{2 \mathrm{i}}^{\bullet}\right)^{\theta}\right\}},
$$

14. Dynamics of the i economy along the linearized path governed by (28)

Solving (28), one obtains:

$$
\begin{aligned}
& \mathrm{h}_{2 \mathrm{it}}-\mathrm{h}_{2 \mathrm{i}}= \mathrm{e}_{11}\left\{\left[\frac{\left(\mathrm{h}_{2 \mathrm{i} 0}-\mathrm{h}_{2 \mathrm{i}}\right)-\mathrm{e}_{12}\left(\mathrm{H}_{\mathrm{i} 0}-\mathrm{H}_{\mathrm{i}}^{\bullet}\right)}{\mathrm{e}_{11}-\mathrm{e}_{12}}\right] \chi_{1}^{\mathrm{t}}+\left(\mathrm{p}_{11} \mathrm{u}_{11}+\mathrm{p}_{21} \mathrm{u}_{12}\right) \mathrm{v}_{\mathrm{i} 0}^{\frac{\sigma-1}{\sigma}} \sum_{\mathrm{j}=0}^{\mathrm{t}-1} \chi_{1}^{\mathrm{j}} \chi_{3} \frac{(\sigma-1)(\mathrm{t}-1-\mathrm{j})}{\sigma}\right\}+ \\
&+\mathrm{e}_{12}\left\{\left[\frac{\mathrm{e}_{11}\left(\mathrm{H}_{\mathrm{i} 0}-\mathrm{H}_{\mathrm{i}}^{\bullet}\right)-\left(\mathrm{h}_{2 \mathrm{i} 0}-\mathrm{h}_{2 \mathrm{i}}\right)}{\mathrm{e}_{11}-\mathrm{e}_{12}}\right] \chi_{2}^{\mathrm{t}}+\left(\mathrm{p}_{11} \mathrm{u}_{21}+\mathrm{p}_{21} \mathrm{u}_{22}\right) \mathrm{v}_{\mathrm{i} 0}^{\frac{\sigma-1}{\sigma}} \sum_{\mathrm{j}=0}^{\mathrm{t}-1} \chi_{2}^{\mathrm{j}} \frac{(\sigma-1)(\mathrm{t}-1-\mathrm{j})}{\sigma}\right\}, \mathrm{i}=\mathrm{us}, \mathrm{eu}, \\
& \mathrm{H}_{\mathrm{it}}-\mathrm{H}_{\mathrm{i}}=\left[\frac{\left(\mathrm{h}_{2 \mathrm{i} 0}-\mathrm{h}_{2 \mathrm{i}}\right)-\mathrm{e}_{12}\left(\mathrm{H}_{\mathrm{i} 0}-\mathrm{H}_{\mathrm{i}}\right)}{\mathrm{e}_{11}-\mathrm{e}_{12}}\right] \chi_{1}^{\mathrm{t}}+\left(\mathrm{p}_{11} \mathrm{u}_{11}+\mathrm{p}_{21} \mathrm{u}_{12}\right) \mathrm{v}_{\mathrm{i} 0} \frac{\sigma-1}{\sigma} \sum_{\mathrm{j}=0}^{\mathrm{t}-1} \chi_{1}^{\mathrm{j}} \frac{(\sigma-1)(\mathrm{t}-1-\mathrm{j})}{\sigma}+ \\
&+\left[\frac{\mathrm{e}_{11}\left(\mathrm{H}_{\mathrm{i} 0}-\mathrm{H}_{\mathrm{i}}^{\bullet}\right)-\left(\mathrm{h}_{2 \mathrm{i} 0}-\mathrm{h}_{2 \mathrm{i}}\right)}{\mathrm{e}_{11}-\mathrm{e}_{12}}\right] \chi_{2}^{\mathrm{t}}+\left(\mathrm{p}_{11} \mathrm{u}_{21}+\mathrm{p}_{21} \mathrm{u}_{22}\right) \mathrm{v}_{\mathrm{i} 0}^{\frac{\sigma-1}{\sigma}} \sum_{\mathrm{j}=0}^{\mathrm{t}-1} \chi_{2}^{\mathrm{j}} \frac{(\sigma-1)(\mathrm{t}-1-\mathrm{j})}{\sigma}, \mathrm{i}=\mathrm{us}, \mathrm{eu},
\end{aligned}
$$

where $\chi_{1}$ and $\chi_{2}$ are the eigenvalues of $\mathrm{B}, \chi_{3}=\left[\beta\left(1-\delta+\theta\left(\mathrm{h}_{2 \mathrm{i}}\right)^{1-\theta}\right]^{-1}, \mathrm{E}=\left[\begin{array}{cc}\mathrm{e}_{11} & \mathrm{e}_{12} \\ 1 & 1\end{array}\right]\right.$ is the matrix of the eigenvectors of $B, \quad E^{-1}=\left[\begin{array}{ll}u_{11} & u_{12} \\ u_{21} & u_{22}\end{array}\right]$ is the inverse of matrix $E$, and $H_{0}$ is given. Notice that $\chi_{1}, \chi_{2}=\frac{\mathrm{b}_{11}+\mathrm{b}_{22}}{2} \pm\left[\left(\frac{\mathrm{b}_{11}+\mathrm{b}_{22}}{2}\right)^{2}-\mathrm{b}_{11} \mathrm{~b}_{22}+\mathrm{b}_{12} \mathrm{~b}_{21}\right]^{\frac{1}{2}}, \mathrm{e}_{11}=\frac{1-\lambda-\chi_{1}}{\lambda}$ and $\mathrm{e}_{12}=\frac{1-\lambda-\chi_{2}}{\lambda}$

As a numerical example, let $m\left(\mathrm{H}_{\mathrm{t}}\right)=0.0754504+0.0214678 \mathrm{H}_{\mathrm{t}}, \mathrm{N}=100, \beta=0.95, \delta=0.05, \theta=0.35, \lambda=0.1, \sigma=1,5$, $\tau_{\mathrm{us}}=0.3, \tau_{\mathrm{eu}}=0.4179614$. Given these values, one has: $\mathrm{h}_{2 \mathrm{us}}^{\bullet}=30, \mathrm{~h}_{1 \mathrm{us}}^{\bullet}=0, \mathrm{H}_{\mathrm{us}}^{\bullet}=\mathrm{L}_{\mathrm{us}}^{\bullet}=70$, and $\mathrm{h}_{2 \mathrm{eu}}^{\bullet}=25$, $\mathrm{h}_{1 \mathrm{eu}}^{\bullet}=0, \mathrm{H}_{\mathrm{eu}}^{\bullet}=\mathrm{L}_{\mathrm{eu}}^{\bullet}=75$. In a neighborhood of $\left(\mathrm{h}_{2 \mathrm{us}}^{\bullet}, \mathrm{H}_{\mathrm{us}}^{\bullet}, \mathrm{v}_{\mathrm{us}}^{\bullet}\right)$, one has: $\chi_{1}=0.8884765, \chi_{2}=0.3476082$, $\chi_{3}=0.2540756$, thus guaranteeing asymptotic convergence. Moreover, if $\mathrm{H}_{\mathrm{us} 0}=\mathrm{H}_{0}=69$, one may have $\mathrm{h}_{2 \mathrm{us} 0}=28<\mathrm{h}{ }_{2}$ us , $\mathrm{h}_{1 \mathrm{us} 0}=h_{1}\left(\mathrm{~h}_{2 \mathrm{us} 0}, \mathrm{H}_{\mathrm{us} 0}, \mathrm{v}_{\mathrm{us} 0}\right)=10.615806>\mathrm{h}_{1 \mathrm{us}}^{\bullet}$ and $\mathrm{L}_{\mathrm{us} 0}=L\left(\mathrm{~h}_{2 \mathrm{us} 0}, \mathrm{H}_{\mathrm{us} 0}, \mathrm{v}_{\mathrm{us} 0}\right)=61.384194<\mathrm{L}_{\text {us }}^{\bullet}$. In a neighborhood of 
$\left(\mathrm{h}_{2 \mathrm{eu}}, \mathrm{H}_{\mathrm{eu}}^{\bullet}, \mathrm{v}_{\mathrm{eu}}^{\bullet}\right)$, one has: $\chi_{1}=0.8885769, \chi_{2}=0.3843945, \chi_{3}=0.2780217$, thus guaranteeing asymptotic convergence. Moreover, if $\mathrm{H}_{\mathrm{eu} 0}=\mathrm{H}_{0}=72.5, \quad$ one $\quad$ may have $\mathrm{h}_{2 \mathrm{eu} 0}=28>\mathrm{h}_{2 \mathrm{eu}}^{\bullet}$, $\mathrm{h}_{1 \mathrm{eu} 0}=h_{1}\left(\mathrm{~h}_{2 \mathrm{eu} 0}, \mathrm{H}_{\mathrm{eu} 0}, \mathrm{v}_{\mathrm{eu} 0}\right)=10.615806>\mathrm{h}_{\text {eu }}^{\bullet}$ and $\mathrm{L}_{\mathrm{eu} 0}=L\left(\mathrm{~h}_{2 \mathrm{eu} 0}, \mathrm{H}_{\mathrm{eu} 0}, \mathrm{v}_{\mathrm{eu} 0}\right)=61.384194<\mathrm{L}_{\mathrm{eu}}^{\bullet}$.

15. Values of $z_{1}$ and $z_{2}$ in (29)

By linearizing (13) and (26) (with $\left.\mathrm{H}_{\mathrm{t}+1}=\mathrm{H}_{\mathrm{t}}=\mathrm{H}_{0}\right)$ around $\left(\mathrm{h}_{2 \mathrm{i}}^{\circ}, \mathrm{v}_{\mathrm{i}}^{\circ}\right)$, one can obtain (29), where $\mathrm{z}_{1}=F_{1}\left(\mathrm{~h}_{2 \mathrm{i}}^{\circ}, \mathrm{v}_{\mathrm{i}}^{\circ}\right.$ ) (see (A13)) and $\mathrm{z}_{2}=G_{1}\left(\stackrel{\circ}{\circ} \stackrel{\circ}{\circ}, \stackrel{\circ}{\circ},{ }_{\mathrm{i}}^{\circ}\right)(\operatorname{see}(\mathrm{A} 15))$.

16. Numerical example showing that there exist parameter values consistent with both $\beta\left[1-\delta+\theta\left(\mathrm{h}_{2 \mathrm{i}}^{\circ}\right)^{1-\theta}\right]>1$ and $0<z_{1}<1$

As a numerical example, let $m\left(\mathrm{H}_{\mathrm{t}}\right)=0.0754504+0.0214678 \mathrm{H}_{\mathrm{t}}, \mathrm{N}=100, \beta=0.95, \delta=0.05, \theta=0.35, \lambda=0.1, \sigma=1.5$ and

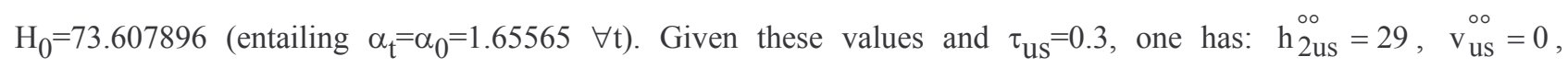
$\beta\left[1-\delta+\theta\left(\mathrm{h}_{2 \mathrm{us}}^{\circ \mathrm{ou}}\right)^{1-\theta}\right]=3.8697241$ and $\mathrm{z}_{1}=0.3423479 ;$ given these values and $\tau_{\mathrm{eu}}=0.4179614$, one has:

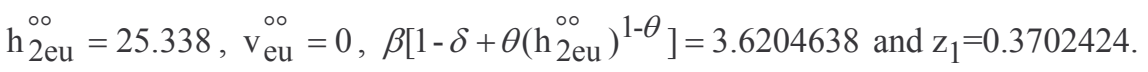

\section{References}

Aguiar, M. and Hurst, E. (2006), "Measuring trends in Leisure: The Allocation of Time over Five Decades," Working Paper No. 06-2, Federal Reserve Bank of Boston.

Alesina, A., Glaeser, E. and Sacerdote, B. (2005), "Work and Leisure in the US and Europe: Why So Different?," paper prepared for the NBER Macroeconomic Annual 2005.

Aronsson, T. and Sjögren, T. (2006), "Optimal Income Taxation and Social Norms in the Labor Market," mimeo, Department of Economics, Umeå University.

Arrow, K.J. (1974), The Limits of Organization, Norton, New York.

Bandura, A. (1977), Social Learning Theory, Prentice-Hall, Englewood Cliffs.

Bandura, A. (1986), Social Foundations of Thought and Action. - A Social Cognitive Theory, Prentice-Hall, Upper Saddle River.

Barro, R.J. and Sala-i-Martin, X. (1995), Economic Growth, McGraw-Hill, New York.

Becker, G.S. (1996), Accounting for Tastes, Harvard University Press, Cambridge. 
Becker, G.S. and Madrigal, V. (1994), "The Formation of Values with Habitual Behavior," mimeo, Department of Economics, University of Chicago.

Bell, L.A. and Freeman R.B. (1995), "Why Do Americans and Germans Work Different Hours?." In: Buttler, F., Franz, W., Schettkat R. and Soskice, D. (eds.), Institutional Frameworks and Labor Market Performance, Routledge, London.

Bell, L.A. and Freeman R.B. (2001), “The Incentive for Working Hard: Explaining Hours Worked Differences in the US and Germany," Labour Economics 8: 181-202.

Binder, M. and Niederle, U.-M. (2006), "Institutions as Determinants of Preference Change. - A One Way Relation?," Papers on Economics and Evolution No. 0607, Max Planck Institute of Economics.

Bisin, A. and Verdier, T. (1998), "On the Cultural Transmission of Preferences for Social Status," Journal of Public Economics 70: 75-97.

Blanchard, O. (2004), “The Economic Future of Europe,” NBER Working Paper No. 10310, National Bureau of Economic Research.

Blanchard, O. and Wolfers, J. (2004), "The Role of Shocks and Institutions in the Rise of European Unemployment: The Aggregate Evidence," Economic Journal 110, 1-33.

Blomquist, S.N. (1993), "Interdependent Behavior and the Effect of Taxes," Journal of Public Economics 51: $211-218$.

Bowles, S. (1998), "Endogenous Preferences: The Cultural Consequences of Markets and Other Economic Institutions," Journal of Economic Literature 36: 75-111.

Burda, M.C., Hamermesh, D.S. and Weil, P. (2006), ”Different but Equal: Total Work, Gender and Social Norms in EU and US Time Use," paper prepared for the Conference of the Fondazione Rodolfo Debenedetti “Are Europeans Lazy? Or Americans Crazy?” held in Portovenere (Italy) on May 27. Davis, S.J. and Henrekson, M. (2004), "Tax Effects on Work Activity, Industry Mix and Shadow Economy Size: Evidence from Rich-Country Comparisons,” NBER Working Paper No. 10509, National Bureau of Economic Research.

Ebbinghaus, B. and Visser, J. (2000), Trade Unions in Western Europe since 1945, London/New York: Macmillan/Grove. 
Faria, J.R. and León-Ledesma, M.A. (2004), "Habit Formation, Work Ethics and Technological Progress," Manchester School 72: 403-413.

Fernandez, R. and Fogli, A. (2005), “Culture: An Empirical Investigation of Beliefs, Work, and Fertility,” Research Department Staff Report 361, Federal Reserve Bank of Minneapolis.

Frankel, M. (1962), "The Production Function in Allocation and Growth: A Synthesis," American Economic Review 52: 995-1022.

Freeman, R.B. and Schettkat, R. (2005), "Marketization of Household Production and the EU-US Gap in Work", Economic Policy 20, No. 41: 6-50.

Glaeser, E., Sacerdote, B. and Scheinkman, J.A. (2002), “The Social Multiplier,” HIER Discussion Paper No. 1968, Harvard Institute of Economic Research.

Greif, A. (1994), "Cultural Beliefs and the Organization of Society: A Historical and Theoretical Reflection on Collectivist and Individualist Societies," Journal of Political Economy 102: 912-950.

Gurdgiev, C.T. (2004), “A Life-Cycle Model of Habitual Dependence in Leisure Demand,” mimeo, Department of Economics, Trinity College, Dublin.

Jakee, K. and Guang-Zhen S. (2005), "External Habit Formation and Dependency in the Welfare State," European Journal of Political Economy 21: 83-98.

Katona, G., Strumpel, B. and Zahn, E. (1971), Aspirations and Affluence: Comparative Studies in the US and Western Europe, McGraw-Hill, New York.

Kreps, D.M. (1997), “Intrinsic Motivation and Extrinsic Incentives,” American Economic Review Papers and Proceedings 87: 359-364.

Lindbeck, A. (1995), "Welfare State Disincentives with Endogenous Habits and Norms," Scandinavian Journal of Economics 97: 477-494.

Lindbeck, A., Nyberg, S. and Weibull, J.W. (1999), "Social Norms and Economic Incentives in the Welfare State," Quarterly Journal of Economics 114: 1-35.

Nickell, S. (2003), “Work and Taxes,” CESifo Working Paper No. 1109, CESifo, Munich.

North, D.C. (1990), Institutions, Institutional Change and Economic Performance, Cambridge University Press, New York.

OECD (1998), Employment Outlook, OECD, Paris. 
Olovsson, C. (2004), "Why Do Europeans Work So Little?," Institute for International Economic Studies Seminar Paper No. 727, Stockholm University.

Posner, R.A. (1997), "Social Norms and the Law," American Economic Review Papers and Proceedings 87: 365-369.

Prescott, E.C. (2004), "Why Do Americans Work So Much More than Europeans?," Federal Reserve Bank of Minneapolis Quarterly Review 28, No. 1: 2-13.

Ragan, K.S. (2005),'Taxes, Transfers and Time Use: Fiscal Policy in a Household Production Model," mimeo, Department of Economics, University of Chicago.

Rogerson, R. (2005), "Structural Transformation and the Deterioration of European Labor Market Outcomes," mimeo, Department of Economics, Arizona State University.

Woittiez, I. and Kapteyn, A. (1998), "Social Interactions and Habit Formation in a Model of Female Labour Supply," Journal of Public Economics 70: 185-205. 
Elenco dei papers del Dipartimento di Economia

2000.1 A two-sector model of the effects of wage compression on unemployment and industry distribution of employment, by Luigi Bonatti

2000.2 From Kuwait to Kosovo: What have we learned? Reflections on globalization and peace, by Roberto Tamborini

2000.3 Metodo e valutazione in economia. Dall'apriorismo a Friedman, by Matteo Motterlini

2000.4 Under tertiarisation and unemployment. by Maurizio Pugno

2001.1 Growth and Monetary Rules in a Model with Competitive Labor Markets, by Luigi Bonatti.

2001.2 Profit Versus Non-Profit Firms in the Service Sector: an Analysis of the Employment and Welfare Implications, by Luigi Bonatti, Carlo Borzaga and Luigi Mittone.

2001.3 Statistical Economic Approach to Mixed Stock-Flows Dynamic Models in Macroeconomics, by Bernardo Maggi and Giuseppe Espa.

2001.4 The monetary transmission mechanism in Italy: The credit channel and a missing ring, by Riccardo Fiorentini and Roberto Tamborini.

2001.5 Vat evasion: an experimental approach, by Luigi Mittone

2001.6 Decomposability and Modularity of Economic Interactions, by Luigi Marengo, Corrado Pasquali and Marco Valente.

2001.7 Unbalanced Growth and Women's Homework, by Maurizio Pugno

2002.1 The Underground Economy and the Underdevelopment Trap, by Maria Rosaria Carillo and Maurizio Pugno.

2002.2 Interregional Income Redistribution and Convergence in a Model with Perfect Capital Mobility and Unionized Labor Markets, by Luigi Bonatti.

2002.3 Firms' bankruptcy and turnover in a macroeconomy, by Marco Bee, Giuseppe Espa and Roberto Tamborini.

2002.4 One "monetary giant" with many "fiscal dwarfs": the efficiency of macroeconomic stabilization policies in the European Monetary Union, by Roberto Tamborini.

2002.5 The Boom that never was? Latin American Loans in London 18221825, by Giorgio Fodor. 
2002.6 L'economia senza banditore di Axel Leijonhufoud: le 'forze oscure del tempo e dell'ignoranza' e la complessità del coordinamento, by Elisabetta De Antoni.

2002.7 Why is Trade between the European Union and the Transition Economies Vertical?, by Hubert Gabrisch and Maria Luigia Segnana.

2003.1 The service paradox and endogenous economic gorwth, by Maurizio Pugno.

2003.2 Mappe di probabilità di sito archeologico: un passo avanti, di Giuseppe Espa, Roberto Benedetti, Anna De Meo e Salvatore Espa.

(Probability maps of archaeological site location: one step beyond, by Giuseppe Espa, Roberto Benedetti, Anna De Meo and Salvatore Espa).

2003.3 The Long Swings in Economic Understianding, by Axel Leijonhufvud.

2003.4 Dinamica strutturale e occupazione nei servizi, di Giulia Felice.

2003.5 The Desirable Organizational Structure for Evolutionary Firms in Static Landscapes, by Nicolás Garrido.

2003.6 The Financial Markets and Wealth Effects on Consumption An Experimental Analysis, by Matteo Ploner.

2003.7 Essays on Computable Economics, Methodology and the Philosophy of Science, by Kumaraswamy Velupillai.

2003.8 Economics and the Complexity Vision: Chimerical Partners or Elysian Adventurers?, by Kumaraswamy Velupillai.

2003.9 Contratto d'area cooperativo contro il rischio sistemico di produzione in agricoltura, di Luciano Pilati e Vasco Boatto.

2003.10 Il contratto della docenza universitaria. Un problema multi-tasking, di Roberto Tamborini.

2004.1 Razionalità e motivazioni affettive: nuove idee dalla neurobiologia e psichiatria per la teoria economica? di Maurizio Pugno.

(Rationality and affective motivations: new ideas from neurobiology and psychiatry for economic theory? by Maurizio Pugno.

2004.2 The economic consequences of Mr. G. W. Bush's foreign policy. Can th US afford it? by Roberto Tamborini

2004.3 Fighting Poverty as a Worldwide Goal by Rubens Ricupero

2004.4 Commodity Prices and Debt Sustainability by Christopher L. Gilbert and Alexandra Tabova 
2004.5 A Primer on the Tools and Concepts of Computable Economics by K. Vela Velupillai

2004.6 The Unreasonable Ineffectiveness of Mathematics in Economics by Vela K. Velupillai

2004.7 Hicksian Visions and Vignettes on (Non-Linear) Trade Cycle Theories by Vela K. Velupillai

2004.8 Trade, inequality and pro-poor growth: Two perspectives, one message? By Gabriella Berloffa and Maria Luigia Segnana

2004.9 Worker involvement in entrepreneurial nonprofit organizations. Toward a new assessment of workers? Perceived satisfaction and fairness by Carlo Borzaga and Ermanno Tortia.

2004.10 A Social Contract Account for CSR as Extended Model of Corporate Governance (Part I): Rational Bargaining and Justification by Lorenzo Sacconi

2004.11 A Social Contract Account for CSR as Extended Model of Corporate Governance (Part II): Compliance, Reputation and Reciprocity by Lorenzo Sacconi

2004.12 A Fuzzy Logic and Default Reasoning Model of Social Norm and Equilibrium Selection in Games under Unforeseen Contingencies by Lorenzo Sacconi and Stefano Moretti

2004.13 The Constitution of the Not-For-Profit Organisation: Reciprocal Conformity to Morality by Gianluca Grimalda and Lorenzo Sacconi

2005.1 The happiness paradox: a formal explanation from psycho-economics by Maurizio Pugno

2005.2 Euro Bonds: in Search of Financial Spillovers by Stefano Schiavo

2005.3 On Maximum Likelihood Estimation of Operational Loss Distributions by Marco Bee

2005.4 An enclave-led model growth: the structural problem of informality persistence in Latin America by Mario Cimoli, Annalisa Primi and Maurizio Pugno

2005.5 A tree-based approach to forming strata in multipurpose business surveys, Roberto Benedetti, Giuseppe Espa and Giovanni Lafratta.

2005.6 Price Discovery in the Aluminium Market by Isabel FiguerolaFerretti and Christopher L. Gilbert. 
2005.7 How is Futures Trading Affected by the Move to a Computerized Trading System? Lessons from the LIFFE FTSE 100 Contract by Christopher L. Gilbert and Herbert A. Rijken.

2005.8 Can We Link Concessional Debt Service to Commodity Prices? By Christopher L. Gilbert and Alexandra Tabova

2005.9 On the feasibility and desirability of GDP-indexed concessional lending by Alexandra Tabova.

2005.10 Un modello finanziario di breve periodo per il settore statale italiano: l'analisi relativa al contesto pre-unione monetaria by Bernardo Maggi e Giuseppe Espa.

2005.11 Why does money matter? A structural analysis of monetary policy, credit and aggregate supply effects in Italy, Giuliana Passamani and Roberto Tamborini.

2005.12 Conformity and Reciprocity in the "Exclusion Game": an Experimental Investigation by Lorenzo Sacconi and Marco Faillo.

2005.13 The Foundations of Computable General Equilibrium Theory, by K. Vela Velupillai.

2005.14 The Impossibility of an Effective Theory of Policy in a Complex Economy, by K. Vela Velupillai.

2005.15 Morishima's Nonlinear Model of the Cycle: Simplifications and Generalizations, by K. Vela Velupillai.

2005.16 Using and Producing Ideas in Computable Endogenous Growth, by K. Vela Velupillai.

2005.17 From Planning to Mature: on the Determinants of Open Source Take Off by Stefano Comino, Fabio M. Manenti and Maria Laura Parisi.

2005.18 Capabilities, the self, and well-being: a research in psychoeconomics, by Maurizio Pugno.

2005.19 Fiscal and monetary policy, unfortunate events, and the SGP arithmetics. Evidence from a growth-gap model, by Edoardo Gaffeo, Giuliana Passamani and Roberto Tamborini

2005.20 Semiparametric Evidence on the Long-Run Effects of Inflation on Growth, by Andrea Vaona and Stefano Schiavo.

2006.1 On the role of public policies supporting Free/Open Source Software. An European perspective, by Stefano Comino, Fabio M. Manenti and Alessandro Rossi. 
2006.2 Back to Wicksell? In search of the foundations of practical monetary policy, by Roberto Tamborini

2006.3 The uses of the past, by Axel Leijonhufvud

2006.4 Worker Satisfaction and Perceived Fairness: Result of a Survey in Public, and Non-profit Organizations, by Ermanno Tortia

2006.5 Value Chain Analysis and Market Power in Commodity Processing with Application to the Cocoa and Coffee Sectors, by Christopher L. Gilbert

2006.6 Macroeconomic Fluctuations and the Firms' Rate of Growth Distribution: Evidence from UK and US Quoted Companies, by Emiliano Santoro

2006.7 Heterogeneity and Learning in Inflation Expectation Formation: An Empirical Assessment, by Damjan Pfajfar and Emiliano Santoro

2006.8 Good Law \& Economics needs suitable microeconomic models: the case against the application of standard agency models: the case against the application of standard agency models to the professions, by Lorenzo Sacconi

2006.9 Monetary policy through the "credit-cost channel". Italy and Germany, by Giuliana Passamani and Roberto Tamborini

2007.1 The Asymptotic Loss Distribution in a Fat-Tailed Factor Model of Portfolio Credit Risk, by Marco Bee

2007.2 Sraffa?s Mathematical Economics - A Constructive Interpretation, by Kumaraswamy Velupillai

2007.3 Variations on the Theme of Conning in Mathematical Economics, by Kumaraswamy Velupillai

2007.4 Norm Compliance: the Contribution of Behavioral Economics Models, by Marco Faillo and Lorenzo Sacconi

2007.5 A class of spatial econometric methods in the empirical analysis of clusters of firms in the space, by Giuseppe Arbia, Giuseppe Espa e Danny Quah.

2007.6 Rescuing the LM (and the money market) in a modern Macro course, by Roberto Tamborini.

2007.7 Family, Partnerships, and Network: Reflections on the Strategies of the Salvadori Firm of Trento, by Cinzia Lorandini.

2007.8 I Verleger serici trentino-tirolesi nei rapporti tra Nord e Sud: un approccio prosopografico, by Cinzia Lorandini. 
2007.9 A Framework for Cut-off Sampling in Business Survey Design, by Marco Bee, Roberto Benedetti e Giuseppe Espa

2007.10 Spatial Models for Flood Risk Assessment, by Marco Bee, Roberto Benedetti e Giuseppe Espa

2007.11 Inequality across cohorts of households:evidence from Italy, by Gabriella Berloffa and Paola Villa

2007.12 Cultural Relativism and Ideological Policy Makers in a Dynamic Model with Endogenous Preferences, by Luigi Bonatti

2007.13 Optimal Public Policy and Endogenous Preferences: an Application to an Economy with For-Profit and Non-Profit, by Luigi Bonatti

2007.14 Breaking the Stability Pact: Was it Predictable?, by Luigi Bonatti and Annalisa Cristini.

2007.15 Home Production, Labor Taxation and Trade Account, by Luigi Bonatti.

2007.16 The Interaction Between the Central Bank and a Monopoly Union Revisited: Does Greater Uncertainty about Monetary Policy Reduce Average Inflation?, by Luigi Bonatti.

2007.17 Complementary Research Strategies, First-Mover Advantage and the Inefficiency of Patents, by Luigi Bonatti.

2007.18 DualLicensing in Open Source Markets, by Stefano Comino and Fabio M. Manenti.

2007.19 Evolution of Preferences and Cross-Country Differences in Time Devoted to Market Work, by Luigi Bonatti. 
PUBBLICAZIONE REGISTRATA PRESSO IL TRIBUNALE DI TRENTO 